\title{
ENVIRONMENTALLY COMPATIBLE UTILIZATION OF RECLAIMED MINELANDS FOR SUSTAINABLE PRODUCTION FOOD AND BIOENERGY FEEDSTOCK
}

\author{
Kharytonov M. M., Martynova N. V., Babenko M. G., Rula I. V.
}

\section{INTRODUCTION}

The study of physical, chemical and biological properties of phytomeliorated rocks make it possible to determine the main parameters of lithozem fertility. All these parameters should reflect the passage of the main processes of soil formation in plant meliorated rocks. This also can be applied to the ratio of oxidation and reduction during weathering of overburden rocks and changes in the buffer capacity of lithozems. Assessing the prospects for using rocks for biological reclamation requires detailing the processes of formation of "young" soils on litozems. Mining rocks uptaken to the day surface are represented by loess like loam, red-brown loam and clays, lime, marl clays, sand and other rocks.

Currently, there is also growing interest in converting marginal lands to bioenergy crop production instead of using high quality croplands which could jeopardize food security and soil quality ${ }^{1}$. Perennial $\mathrm{C}_{4}$-grasses such as Switchgrass and Miscanthus, are being actively developed as sources for bioenergy due to many positive features. These plants have characteristics that put them into the possible candidates for biomass production and remediation of soil. They are not an invasive species and are suitable bioenergy crops because of efficient use of available resources, retaining carbon in soil, have a high degree of efficiency of water use and have little requirements for nutrition ${ }^{2,3}$. However, the biomass yield and carbon sequestration performance of Miscanthus and Switchgrass are varied by climate, soil type, management practices, and land-use history ${ }^{4,5}$. Previous researches ${ }^{6,7,8}$ showed that in the

${ }^{1}$ Kharytonov M., Lyadska I., Kozechko V., Kalyna V., Babenko M., Babenko V., Garmash S.M. The nitrates nutrition status assessment and management of the horticultural crops in the steppe zone of Ukraine. ANNALS of Faculty Engineering Hunedoara - International Journal of Engineering. 2019. Tome XVII. P. 127-130.

Scousen J., Brown C. Establishment and growth of switchgrass and other biomass crops on surface mines. Journal American Society of Mining and Reclamation. 2014. Vol.3(1). P. 136-156. URL: https://doi.org/10.21000/JASMR14010136

Ussiri D.A.N., Guzman J.G., Lal R., Somireddy U. Bioenergy crop production on reclaimed mine land in the North Appalachian region, USA. Biomass and Bioenergy. 2019. Vol. 125. P. 188-195. URL: https://doi.org/10.1016/j.biombioe.2019.04.024

${ }^{4}$ Jakovljević M., Lilić N., Kolonja B., Knežević D., Petrić M., Tadić V., Nedić M. Biomass production as renewable energy resource at reclaimed Serbian lignite open-cast mines. Thermal Science. 2015. Vol. 19 (3). P. 823-835. URL: https://doi.org/10.2298/TSCI140626014J 
regions with sufficient water supply, Miscanthus was more than twice as productive as Switchgrass. Both crops were similarly efficient in intercepting sunlight, but Miscanthus showed much higher rates of photosynthesis and was more efficient in its use of water and nitrogen. Although Switchgrass has lower yield potential than Miscanthus, it is very cheap to establish. This suggests that Switchgrass may have an advantage on low quality soils where productivity potential is limited and where the high establishment cost of Miscanthus cannot be recovered. Also under high capital cost conditions and when the price of biomass is low, Switchgrass can have an advantage ${ }^{9,10}$. Marginal land such as idle, degraded, underutilized, reclaimed stripe- or abandoned mine-lands, low quality pasture fields, and brushy, and underutilized lands are still relatively low priced and can be the "solution" to growing crops as feedstock for biofuel and highvalue bio-based products. Growing perennial grasses on marginal lands makes sense to investigate the use "waste nutrients" that are locally or regionally available to promote high yields of bio-feedstock crops ${ }^{11}$. The high productivity of energetic plant plantations can be provided through the use of sewage sludge. The use of sewage sludge could not only increase yield but also positively affect biological and physicochemical properties of soil profile ${ }^{12,13}$. Additionally, together with the reduction and mitigation of

5 Nakajima T., Yamada T., Anzoua K., Kokubo R., Noborio K. Carbon sequestration and yield performances of Miscanthus $\times$ giganteus and Miscanthus sinensis. Carbon Management. 2018. Vol. 9(4). P. 415-423. URL: https://doi.org/10.1080/17583004.2018.1518106

${ }^{6}$ Heaton, E.A., Dohleman F.G., Long S.P. Meeting US Biofuel goals with less land: the potential of Miscanthus. Global Change Biology. 2008. Vol.14. P. 2000-2014. http://dx.doi.org/10.1111/j.1365-2486.2008.01662.x.

Boehmel C, Lewandowski I, Claupein W. Comparing annual and perennial energy cropping systems with different management intensities. Agricultural Systems. 2008. Vol. 96(1-3). P. 224-236. URL: https://doi.org/10.1016/j.agsy.2007.08.004

${ }^{8}$ Dohleman F.G., Heaton E.A., Leakey A.D.B., Long S.P. Does greater leaf-level photosynthesis contribute to greater solar energy conversion efficiency in Miscanthus when compared to switchgrass? Plant. Cell and Envorinmetal. 2009. Vol. 32(11). P. 1525-1537. URL: https://doi.org/10.1111/j.1365-3040.2009.02017.x

Khanna M., Dhengana B., Clifton-Brown J. Costs of producing miscanthus and switchgrass for bioenergy in Illinois. Biomass and Bioenergy. 2008. Vol. 32(6). P. 482-493. https://doi.org/10.1016/j.biombioe.2007.11.003

${ }^{10}$ Sadeghpour A., Hashemi M., DaCosta M., Jahanzad E., Herbert S. Switchgrass establishment influenced by cover crop, tillage system, and weed control. Bioenergy Research. Vol. 7. P. 1402-1410. URL: https://doi.org/10.1007/s12155-014-9485-x

${ }_{11}$ Xiaohan Yang, Ting Li, David Weston, Abhijit Karve, Jessy L. Labbe, Lee E. Gunter, Poornima Sukumar, Anne Borland, Jin-Gui Chen, Stan D. Wullschleger, Timothy J. Tschaplinski, Gerald A. Tuskan (2011) Innovative Biological Solutions to Challenges in Sustainable Biofuels Production. In book:Biofuel Production-Recent Developments and Prospects. Edited by Dr. Marco Aurelio Dos Santos Bernardes. p. 375-414. URL: https://doi.org/10.5772/17473

${ }^{12}$ Stietiya M.H., Wang J.J.(2011) Effect of Organic Matter Oxidation on the Fractionation of Copper, Zinc, Lead, and Arsenic in Sewage Sludge and Amended Soils. J. Environ. Qual. 2011. Vol. 40. P. 1162-117. URL: https://doi.org/10.2134/jeq2011.0008 
the risks posed by heavy metals for humans and ecosystems, new waste management of the restored land as well as markets for their products might be created in the region ${ }^{14,15}$. According to the state standard of Ukraine it is allowed to introduce MSS for growing crops at arable lands a dose of not more than 10 tons/ha for three years. Large doses are possible in the case of mineland reclamation after three years monitoring, calculation of heavy metals uptake with energy crops yield and forthcoming life cycle assessment availability of MSS and other soil amendments application. Besides, application of various soil amendments (sewage sludge, ash, biochar etc.) can affect the bioavailability of metals and the biomass quality ${ }^{16,17,18}$. There is still a significant lack of information on the long-term consequences of using soil amendments related to the growth and absorption capacity of plants, the quality of biomass and its thermal characteristics.

\section{Materials and methods}

A series of physico-chemical and biological analyses were performed during long-term pot and field experiments to answer the above questions about the parameters of stabilization of the nutrient regimes of plant meliorated rocks. Phosphate buffer capacity relative to phosphates was determined follow formula: $\mathrm{PBC}=\mathrm{Q} / \mathrm{I}$, where $\mathrm{Q}$ is the total stock of mobile soil phosphates ("capacity factor"); $\mathrm{I}$ is the equilibrium activity of $\mathrm{H}_{2} \mathrm{PO}^{4-}$, or the equilibrium phosphate potential of soils ("intensity" factor). The $\mathrm{Q} / \mathrm{I}$ ratio shows how much mobile phosphates must pass from their total stock in the solid phase to the soil solution, or must be introduced into the soil to change the activity of $\mathrm{H}_{2} \mathrm{PO}^{4-}$ per unit.

${ }^{13}$ Soudani L., Heilmeier H.,Kharytonov M., Wiche O., Moschner C., Onyshchenko E., Bouchena N. (2017) Fertilization value of municipal sewage sludge for Eucalyptus camaldulensis plants. Biotechnology Reports. Vol. 13. P. 8-12. URL: https://doi.org/10.1016/j.btre.2016.12.001 ${ }^{13}$

${ }^{14}$ Dauber J., Brown C., Fernando A.L., Finnan J., Krasuska E., Ponitka J., Styles D., Thrän D., Van Groenigen K.J., Weih M., Zah R. Bioenergy from "surplus" land: environmental and socio-economic implications. BioRisk. 2012. Vol. 7. P. 5-50. URL: https://doi.org/10.3897/biorisk.7.3036

${ }_{15}$ Brian J.A., Jackson A.P. The behavior of heavy metals in sewage sludge-amended soil. Science of the Total Environment. 1991. Vol. 100. P. 151-176. URL: https://doi.org/10.1016/0048-9697(91)90377-O

${ }^{16}$ Xiao, R., Awasthi M.K., Li R.., Park J., S. Pensky O. Wang J.J., Zhang Z.. (2017). Recent developments in biochar utilization as an additive in organic solid waste composting: a review. Bioresour. Technol. Vol. 246. P. 203-213. URL: https://doi.org/10.1016/i.biortech.2017.07.090

Xiao. R.. Wang J.J., Gaston L.A., Zhou B., Park J.H.. Li R.. Dodla S. K.. Zhang Z. Biochar produced from mineral salt-impregnated chicken manure: fertility properties and potential for carbon sequestration. Waste Management. 2018. Vol. 78. P. 802-810. URL: https://doi.org/10.1016/j.wasman.2018.06.047

${ }^{18}$ Singh R.P., Agrawal M. Potential benefits and risk of land application of sewage

sludge. Waste Management. 2008. Vol. 28(2). P. 347-358. URL: https://doi.org/10.1016/j.wasman.2006.12.010 
Long-term pot experiment was conducted follow the principle of crop rotation (the first two years - alfalfa, fallow, barley, peas, barley, corn). This crop rotation cycle was repeated four times. Three options for starting fertilization (control, PK, manure) were taken into account when calculating the uptake of macroelements.

Long-term field experiments with horticultural crops on the reclaimed minelands lands were settled in the Pokrov land reclamation station in the mid-70s of the last century. The first task was to assess the suitability of rocks for growing horticultural crops on reclaimed land. The next step was to develop a technology for growing long-term orchard plantations on reclaimed land. The obtained data allowed us to clarify the biological properties and requirements for the location of horticultural crops. Several model versions of reclaimed mineland were laid 40 years ago. In the test options provided for the apple trees planting without the local and with local application of topsoil. Two types of pits were settled. The volume of pits regarding the first type (type A) was $1 \mathrm{~m}^{3}$. Their dimensions: length $1.4 \mathrm{~m}$, width $1.0 \mathrm{~m}$, depth $0.7 \mathrm{~m}$. The pits were filled with a mass of loess like loam and black soil depending on the scheme of the experiment. In the first trial (type A), the pits were filled depending on the scheme of the experiment: completely - a mass of loess like loam. Next options: a mixture of black soil (50\%) and 50\% of loess like loam (II option); black soil (III option); black soil mass and mineral fertilizers (IV option); black soil, mineral fertilizers and manure (V option). Pits of the second type (type B) had a diameter of $0.8 \mathrm{~m}$ and a depth of $1 \mathrm{~m}$. They were filled with black soil mass and manure (VI option), black soil mass, manure and mineral fertilizers (VII option). The amount of fertilizers applied per pit was appropriate: ammonium nitrate 300 $\mathrm{g}$, superphosphate $500 \mathrm{~g}$, potassium salt $200 \mathrm{~g}$, manure $20 \mathrm{~kg}$. Giant Miscanthus (Miscanthus $\times$ giganteus J.M.Greef et Deuter ex Hodk. et Renvoize) and Switchgrass (Panicum virgatum L.) were studied. The research was conducted over three years (2016-2018) at Pokrov land reclamation station of Dnipro State Agrarian and Economic University, standing at $47^{\circ} 39^{\prime} \mathrm{N}, 34^{\circ} 08^{\prime} \mathrm{E}$, with an elevation of $60 \mathrm{~m}$. The station is located in the Dnipropetrovsk region at the Nikopol manganese ore deposit. This is the steppe zone of Ukraine with moderately continental climate: dry and hot summer and moderate winter. The hottest month is July with the average temperature $+22.0^{\circ} \mathrm{C}$, the coldest is January with the average temperature $-4.1^{\circ} \mathrm{C}$. The region is characterized by an unstable water supply with often prolonged droughts in the summer. The annual rainfall is $465 \mathrm{~mm}, 274 \mathrm{~mm}$ of which belongs to the warm period (April-October) and $191 \mathrm{~mm}$ refers to the cold period (November-March). Seedlings were planted in the experimental plots into a mixture of loess-like loam and redbrown clay passed through a long-term phytomelioration stage. The humus content in the substrate was not exceeded $1.5 \%$. The ratio of humic and fulvic acids was in the range $0.2-0.5$, which indicates a low level of humus 
accumulation and active destruction of the soil mineral part. The following five amendments were used to determine the effect of various additional fertilizers: ash of sunflower husk in amount $10 \mathrm{t} \mathrm{ha}^{-1}$, municipal sewage sludge $\left(10 \mathrm{t} \mathrm{ha}^{-1}\right)$, mixture of ash and sewage sludge $\left(10 \mathrm{t} \mathrm{ha}^{-1}\right)$, a double dose of sludge $\left(20 \mathrm{tha}^{-1}\right)$ and mineral fertilizer with a balance of nutrients $\mathrm{N}_{60}: \mathrm{P}_{60}: \mathrm{K}_{60} \mathrm{~kg} \mathrm{ha}^{-1}$. All amendments were put into the soil in dry form annually once in spring. The biometric parameters and biomass productivity were defined at the end of vegetation season (second part of September). Plant height was measured with a measuring ruler. The stem diameter was determined by caliper at $15 \mathrm{~cm}$ height above the ground surface by clamping the caliper on to a random plant tiller. The number of stems per $\mathrm{m}^{2}$ was counted as well. Than the above-ground biomass was cut to a height $10 \mathrm{~cm}$ from the land surface and weighed in a wet state. The wet biomass was dried until a constant weight in order to estimate the above-ground dry matter yield. The content of mineral elements in biomass was determined. For analysis, biomass samples weighing $2 \mathrm{~g}$ each were combusted in a muffle furnace at $450^{\circ} \mathrm{C}$ by means of drying method and then dissolved in $5 \mathrm{ml}$ of $6 \mathrm{~N}$ spectral purity hydrochloric acid. The content of mineral elements in obtained mineralizes was measured using atomic absorption spectrophotometry method. The received data represented the arithmetic means of three replicates of each sample, their ranges and standard deviations values. The thermal characterisctics of energy crops (Miscanthus and Switchgrass) and trees (Elaeagnus, Populus, Salix and Paulownia) were measured using thermogravimetric analysis. It was performed at derivatograph Q-1500D of the "F. Paulik-J. Paulik-L. Erdey" system. The weight of sample used for analysis was $100 \mathrm{mg}$. The differential mass loss and heating effects were recorded, and the results of the measurements were processed using software package supplied with the device. The samples of biomass were analyzed dynamically at a heating rate of $10^{\circ} \mathrm{C} / \mathrm{min}$ in an air atmosphere. The reference substance was aluminum oxide. As a criterion for assessing the thermal stability of biomass, the activation energy of thermal oxidative destruction was determined using the double logarithm method of Broido $^{19}$. Data received in experiments accomplished were processed by statistical methods using the software package StatGraphics Plus at significance level of $0.95 \%$.

\section{Results and discussion}

The study of the main water-physical properties of the soil mass of the black soil and rocks of the Nikopol manganese deposit was associated with the assessment of the soil texture (in particular, the content of silt and

19 Broido A. A simple, sensitive graphical method of treating thermogravimetric analysis data. J. Polymer of Science. 1969. Vol. 7(3). P. 1761-1763. https://doi.org/10.1002/pol.1969.160071012 
physical clay), the maximum hygroscopicity, and the content of clay minerals of rocks.

The content of silt and physical clay in the soil and rocks of the Nikopol manganese deposit is shown in figure 1. The studied sedimentary deposits of the rock, with the exception of loess-like and red-brown loam (medium loam), ancient alluvial sand (sandy loam) and dark gray clay (heavy loam) are medium-loam. For the content of "physical clay", the soil mass of the black soil is light clay, and the loams and clays studied are medium and heavy clay. The stratum of ancient alluvial sand is characterized as sandy loam, while sand-clay deposits and iron ore slime are light clay (Table 1).

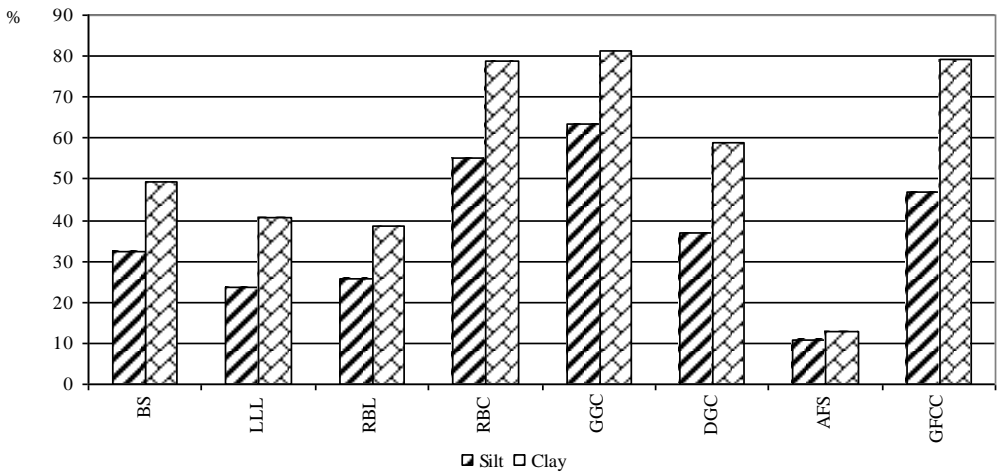

Fig. 1. The content of silt and physical clay in the soil and rocks of the Nikopol manganese deposit, \%

Table 1

Content of clay minerals in soil and rock substrates, \%

\begin{tabular}{|c|c|c|c|}
\hline \multirow{2}{*}{ Substrate } & \multicolumn{3}{|c|}{ Clay mineral } \\
\cline { 2 - 4 } & montmorillonite & hydromica & kaolinite \\
\hline Black soil southern & 9.1 & 14.2 & 9.1 \\
\hline Loess like loam & 6.6 & 9.0 & 7.9 \\
\hline Red-brown clay & 4.3 & 36.5 & 14.4 \\
\hline Gray-green clay & 0.7 & 47.2 & 15.6 \\
\hline Dark-gray clay & 1.6 & 30.8 & 4.7 \\
\hline Ancient alluvial sand & 1.7 & 2.5 & 6.7 \\
\hline Green carbonate-free clay & 31.4 & 11.8 & 3.9 \\
\hline
\end{tabular}

X-ray phase analysis of oriented preparations of clay minerals before and after treatment with ethylene glycol, as well as after firing at a temperature of $550^{\circ} \mathrm{C}$, allowed us to determine the qualitative and quantitative composition of clay minerals of the soil and rocks of the Nikopol manganese deposit. It was determined that the predominant minerals in clay fraction of 
soil and rocks are hydromica, montmorillonite and kaolinite. Gray-green, green carbonate-free, red-brown and dark-grey clay are the most affluent with hydromica and montmorillonite. The redox state of the soil-plant system largely determines the growth and development of plants. It is an integral characteristic of the microbiological, biochemical, and physicochemical processes that take place. The results of studies of the redox potential (Eh), ion activity in the pot experiment, and data obtained after thermodynamic potentials calculations are shown in table 2 .

Table 2

Ion activity and calculations of thermodynamic parameters of black soil and rocks

\begin{tabular}{|c|c|c|c|c|c|c|c|c|c|}
\hline Substrate & $\mathrm{pH}$ & $\begin{array}{c}\mathrm{Eh}, \\
m v\end{array}$ & $\mathrm{rH}_{2}$ & $\mathrm{pCa}$ & $\mathrm{pK}$ & $\mathrm{pNO}_{3}$ & $\begin{array}{c}\mathrm{pH}- \\
0,5 \mathrm{pCa}\end{array}$ & $\begin{array}{c}\mathrm{pK}- \\
0,5 \mathrm{pCa}\end{array}$ & $\begin{array}{c}\mathrm{pH}- \\
\mathrm{pK}\end{array}$ \\
\hline Black soil & 7.12 & 523 & 32.2 & 2.8 & 2.35 & 3.0 & 5.72 & 0.95 & 4.77 \\
\hline $\begin{array}{c}\text { Loess like } \\
\text { loam }\end{array}$ & 8.2 & 475 & 32.8 & 2.7 & 4.3 & 2.95 & 6.85 & 2.95 & 3.9 \\
\hline $\begin{array}{c}\text { Red- } \\
\text { brown } \\
\text { clay }\end{array}$ & 7.7 & 507 & 32.9 & 2.5 & 3.2 & 2.9 & 6.45 & 1.95 & 4.5 \\
\hline $\begin{array}{c}\text { Gray- } \\
\text { green clay }\end{array}$ & 8.4 & 499 & 34.0 & 2.9 & 3.4 & 2.5 & 6.95 & 1.95 & 5.0 \\
\hline
\end{tabular}

The black soil was characterized by highest value of Eh, and the lowest index has got loess like loam. The loess like loam has a more alkaline reaction of the water phase (by $1.08 \mathrm{pH}$ units) in comparison with the black soil. The Eh fluctuations in the studied soil and rocks were in the range of 475-523 $\mathrm{mv}$. The $\mathrm{rH}_{2}$ indicates the predominance of oxidative or reducing processes in the greater or lesser side of the number 27. $\mathrm{The}^{\mathrm{rH}} \mathrm{H}_{2}$ value for all soil and rock samples is greater than 27. Oxidative processes in rocks brought to the surface were predominant. The best conditions for potash nutrition are marked by black soil, red-brown and gray-green clay in accordance with the calculations of potash potential for $\mathrm{pH}-\mathrm{pK}$ index. Graygreen clay is also determined to be a more favorable substrate for passing the processes of mineralization of organic matter of root residues, since the activity of $\mathrm{pNO}_{3}$ ions here was 2.5 . The study of the distribution of Eh in the profiles of pre-formed rocks revealed its highest value at a depth of $20 \mathrm{~cm}$ in red-brown and gray-green clay, and for loess like loam at a depth of $30 \mathrm{~cm}$ (Table 3). 


\section{Table 3}

The activity of the ions along the profile of plant meliorated rocks

\begin{tabular}{|c|c|c|c|c|c|}
\hline Substrate & $\mathbf{H}, \mathbf{c m}$ & $\mathbf{E h}, \boldsymbol{m} \boldsymbol{v}$ & $\mathbf{p C a}$ & $\mathbf{p K}$ & $\mathbf{p K - 0 , 5} \mathbf{~ p C a}$ \\
\hline \multirow{3}{*}{ Loess like loam } & 10 & 487 & 2.15 & 3.0 & 2.5 \\
\cline { 2 - 6 } & 20 & 501 & 2.7 & 5.05 & 3.7 \\
\cline { 2 - 6 } & 30 & 512 & 3.0 & 4.45 & 2.95 \\
\hline \multirow{3}{*}{ Red-brown clay } & 10 & 485 & 0.77 & 4.15 & 3.77 \\
\cline { 2 - 6 } & 20 & 508 & 1.7 & 3.85 & 3.0 \\
\cline { 2 - 6 } & 30 & 502 & 1.5 & 4.5 & 3.75 \\
\hline \multirow{3}{*}{ Gray-green clay } & 10 & 526 & 0.8 & 2.35 & 1.95 \\
\cline { 2 - 6 } & 20 & 540 & 0.83 & 3.8 & 3.39 \\
\cline { 2 - 6 } & 30 & 520 & 1.25 & 4.0 & 3.39 \\
\hline
\end{tabular}

The highest activity of calcium and potassium is distinguished by the upper 20-centimeter layer of all three studied rocks. Thus, data on Eh and ion activity can be used to assess the redox state of rocks. Studies of the redox state of reclaimed land at the Pokrov land reclamation station revealed the advantage of oxidative processes, which was reflected in the change in ion mobility. Parameters of soil substrates and plant meliorated for 5 years rocks in the pot experiments on the level of potential nitrogen fixation are shown in table 4. All rocks had a low level of potential nitrogen fixation (20-100 times less than in black soil) even after five years of their phytomelioration.

Table 4

Potential nitrogen fixation of black soil and rocks after five years of plant melioration ( $\mathrm{nm} \mathrm{C}_{2} \mathrm{H}_{4}$ / day)

\begin{tabular}{|c|c|}
\hline Soil and rocks & Potential nitrogen fixation \\
\hline Black soil & $68.8 \pm 17.5$ \\
\hline Loess like loam & $3.2 \pm 0.77$ \\
\hline Red-brown loam & $2.5 \pm 0.84$ \\
\hline Red-brown clay & $1.2 \pm 0.15$ \\
\hline Gray-green clay & $1.1 \pm 0.001$ \\
\hline Green carbonate-free clay & $0.7 \pm 0.13$ \\
\hline
\end{tabular}

Studies to determine the nitrogen content in the vegetative mass of barley, peas and corn grown during the application of "artificial" crop rotation on black soil and rocks in a five-year pot experiment were conducted to assess the adaptive potential of crops (Table. 5). 
The nitrogen content in the vegetative mass of barley, peas and maize grown on plant meliorated substrata, $\mathrm{g} / \mathrm{kg}$

\begin{tabular}{|c|c|c|c|}
\hline Substrata & Barley & Pea & Maize \\
\hline Black soil & $9.0 \pm 0.1$ & $25.4 \pm 0.55$ & $5.1 \pm 0.2$ \\
\hline Loess like loam & $8.98 \pm 0.1$ & $23.1 \pm 0.7$ & $5.1 \pm 0.3$ \\
\hline Red-brown loam & $9.3 \pm 0.17$ & $22.37 \pm 1.5$ & $4.9 \pm 0.06$ \\
\hline Red-brown clay & $9.2 \pm 0.19$ & $28.0 \pm 1.0$ & $4.9 \pm 0.05$ \\
\hline Gray-green clay & $9.6 \pm 0.36$ & $24.0 \pm 0.49$ & $5.3 \pm 0.09$ \\
\hline Dark-cgray clay & $10.8 \pm 0.17$ & $23.8 \pm 0.72$ & $5.2 \pm 0.09$ \\
\hline Ancient alluvial sand & $9.4 \pm 0.18$ & $25.5 \pm 1.4$ & $5.3 \pm 0.17$ \\
\hline Green carbonate-free clay & $9.8 \pm 0.37$ & $26.2 \pm 1.3$ & $4.9 \pm 0.03$ \\
\hline
\end{tabular}

The calculated data on the removal of mineral elements with plants that were grown in three variants of the initial application of fertilizers (control, $\mathrm{RC}$, manure) in the first five years of the experiment are shown in table 6.

The macronutrients uptake with alfalfa, barley, peas and corn biomass on gray-green and green carbonate-free clays was equal or even higher than the corresponding indicators at the black soil. The highest degree of ecological and biological compliance during two years alfalfa and peas growing in pot experiment is distinguished for green carbonate-free and gray-green clay. Plant meliorated rock substrates were analyzed for the content of humic acids and fulvic acids after five years of crops growing in a long-term pot experiment (Fig. 2).

The obtained data allowed us to estimate the potential reserves of organic matter in plant meliorated substrates. Differences in the humus composition of plant meliorated rocks are marked by 4-6 times lower content of fulvic acids compared to black soil. The level of humic acids in rocks differs from that of black soil at least to 10 times. The advantage of fulvate humus in the analyzed substrates is associated with a low ratio of humic and fulvic acids (0.2-0.5), which is $2.5-6$ times less than black soil.

Table 6

Nutrition elements uptake from plant biomass for 5 years (g)

\begin{tabular}{|c|c|c|c|c|c|c|}
\hline \multirow{2}{*}{ Substrata } & \multicolumn{2}{|c|}{ Control } & \multicolumn{2}{|c|}{$\mathbf{P}+\mathbf{K}$} & \multicolumn{2}{|c|}{ Manure } \\
\hline & $\mathrm{Ca} / \mathrm{Mg}$ & $\mathbf{P} / \mathbf{K}$ & $\mathrm{Ca} / \mathrm{Mg}$ & $\mathbf{P} / \mathbf{K}$ & $\mathrm{Ca} / \mathrm{Mg}$ & $\mathbf{P} / \mathbf{K}$ \\
\hline \multirow{2}{*}{ Black soil } & 0.91 & $\underline{0.35}$ & 1.68 & 0.60 & 2.4 & 0.64 \\
\hline & $\overline{0.19}$ & $\overline{1.11}$ & 0.38 & 1.72 & 0.46 & $\overline{1.85}$ \\
\hline \multirow{2}{*}{ Loess like loam } & $\underline{0.23}$ & $\underline{0.10}$ & $\underline{0.61}$ & $\underline{0.15}$ & $\underline{0.92}$ & $\underline{0.27}$ \\
\hline & $\overline{0.06}$ & $\overline{0.35}$ & $\overline{0.12}$ & $\overline{0.64}$ & 0.22 & 0.82 \\
\hline \multirow{2}{*}{ Red-brown clay } & $\underline{0.18}$ & $\underline{0.10}$ & 1.68 & 0.32 & 1.45 & $\underline{0.28}$ \\
\hline & $\overline{0.05}$ & $\overline{0.31}$ & $\overline{0.73}$ & $\overline{1.71}$ & 0.68 & 1.75 \\
\hline \multirow{2}{*}{ Gray-green clay } & 1.03 & 0.28 & 1.05 & 0.38 & 1.13 & 0.42 \\
\hline & 0.66 & 1.62 & 0.76 & 2.39 & 0.89 & 2.83 \\
\hline \multirow{2}{*}{$\begin{array}{l}\text { Green carbonate- } \\
\text { free clay }\end{array}$} & $\underline{0.63}$ & $\underline{0.19}$ & $\underline{0.80}$ & 0.37 & $\underline{0.84}$ & 0.44 \\
\hline & $\overline{0.23}$ & $\overline{1.61}$ & $\overline{0.63}$ & $\overline{2.64}$ & $\overline{0.52}$ & $\overline{2.73}$ \\
\hline
\end{tabular}




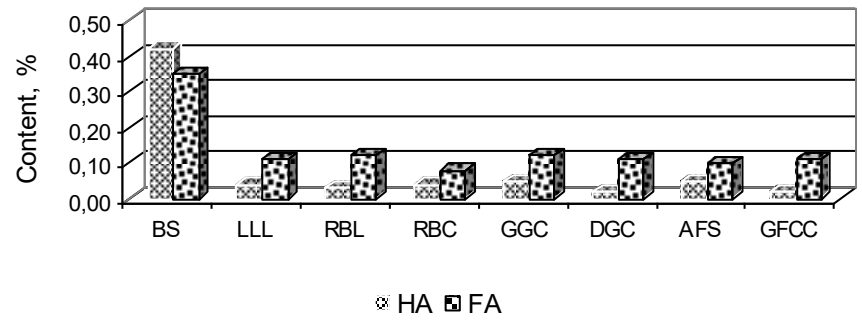

Fig. 2. Concentration of humic and fulvic acids in black soil and rocks after five years of plant melioration, \%

After a long 20-year phytomelioration, the rocks were analyzed again for humus, organic carbon, nitrogen, and phosphorus. The data obtained allow us to estimate the growth rate of the amount of humus and nutrients in the plant meliorated substrates of soil and rocks (Fig. 3 and 4). As shown in figure 3, the 20-year presence of rocks under the influence of plants contributed to an increase in the amount of humus (5-8 times).

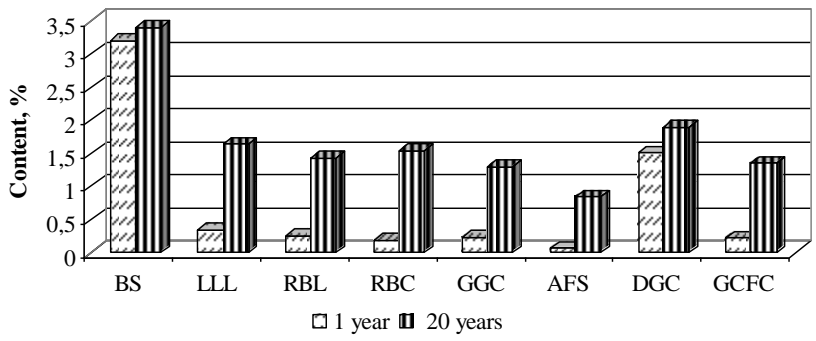

Fig. 3. Changes in humus content in soil and rocks after 20 years of plant melioration

The results of analytical studies of soil and rock samples selected in four typical profiles at the Pokrovsky hospital for reclamation of disturbed lands 20 years after the start of stationary studies made it possible to confirm the leading role of plant melioration (Fig. 4). 


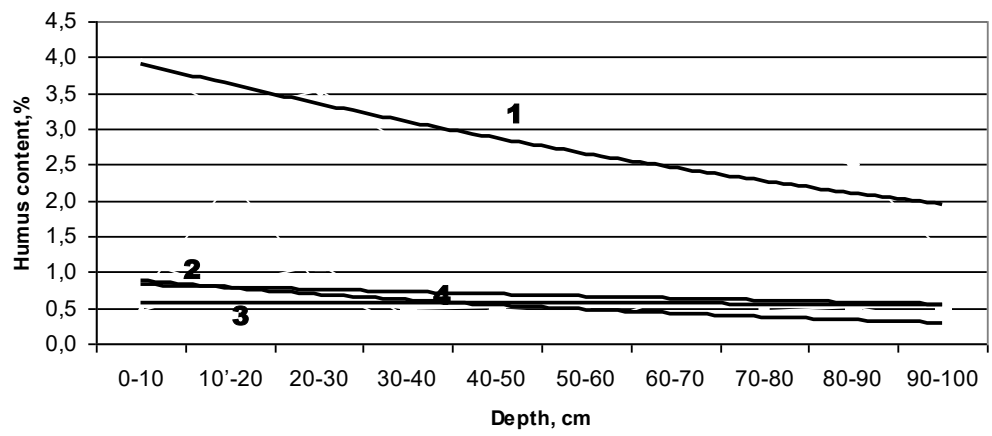

Fig. 4. The humus profile distribution in the soil and plant meliorated rocks ( 1 - black soil; 2 - loess like loam; 3 - red brown clay;

\section{4 - grey green clay)}

In particular, analyses of the humus content showed that the upper layer of plant meliorated rocks, and especially loess like loam, took more influence during the soil formation process. Rock samples that have been under the natural long-growing pioneer phytocenosis for more than 25 years, were selected in layers $(0-5,5-10,10-20,20-40 \mathrm{~cm})$ to study the organic matter formation along profile of reclaimed land. The results of the "active" and "passive" humus determination are shown in figure 5.

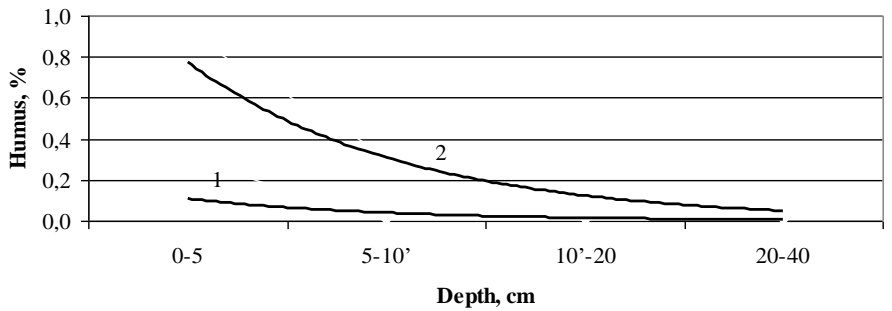

Fig. 5. Layer-by-layer distribution of "active" (1) and "passive"

(2) humus fractions in a mixture of plant meliorated rocks

Calculations show that the content of "active" humus in the layer of $0-5 \mathrm{~cm}$ of plant meliorated rocks is at the level of $25 \%$ of the total. However, its level is reduced to traces in the lower layers.

It is known that at the first stages of reclaimed land development, newly taken to the day surface rocks have low microbiological activity, which results in slow mineralization rates. Therefore, the value of "active" humus 
can be included in the list of parameters for the formation of fertility of plant meliorated rocks.

The results of long-term of pot experiment also confirmed that the rocks phytomelioration over two decades significantly increased the total content of nitrogen and phosphorus in the substrates (Fig. 6).

The nitrogen content increased almost on all rocks, and on ancient alluvial sand by 14 times. The increase in the level of total phosphorus ranged from $28-68 \%$. The study of the phosphates fractional composition in top and subtop soil and plant meliorated rocks can help to clarify the results obtained regarding changes in phosphorus (Fig. 7).

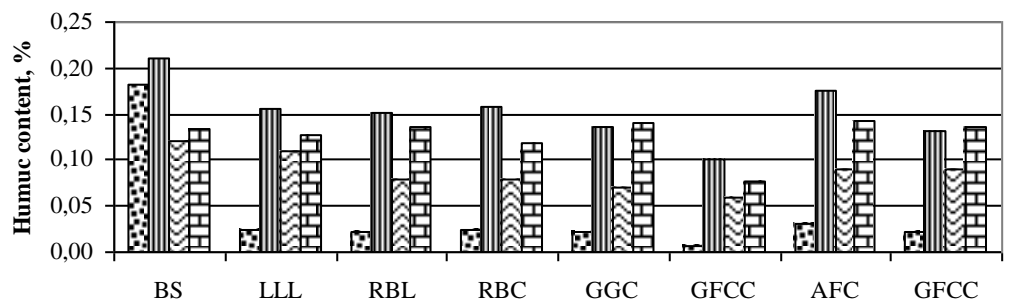

Nitrogen,\% 1year m Nitrogen,\% 20years $\triangle$ Phosphorus, \% 1year $\square$ Phosphorus, \% 20y ears

Fig. 6. Changes in total nitrogen and phosphorus in soil and rocks after 20 years of phytomelioration

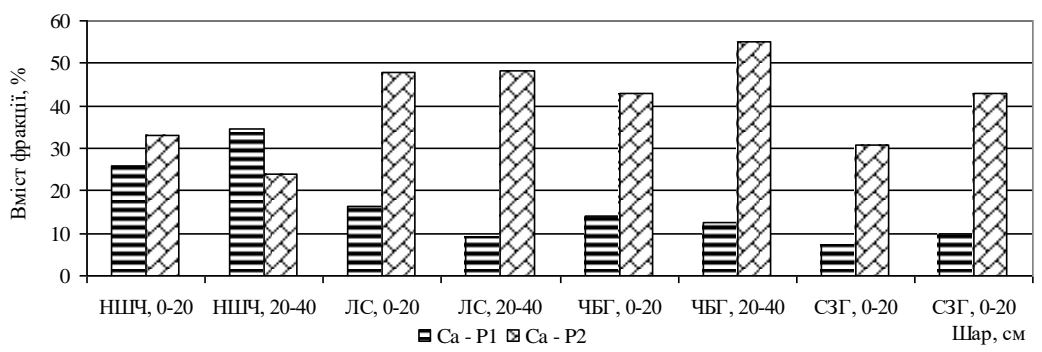

Fig. 7. Ca- $P_{1}$ and Ca- $P_{2}$ fractions composition in top and subtop of soil and plant meliorated rocks

This research has shown that different forms of phosphates are present in the soil mass and rock substrates: dissimilar calcium phosphates, aluminum and iron phosphates. The largest numbers of water-soluble and fragile related calcium phosphates (CA-P $\mathrm{P}_{1}$ fraction) are found in the black soil. 
The content of available forms of phosphorus in rocks is $2-5$ times less. However, the percentage of the near-term phosphate reserve (CA- $\mathrm{P}_{2}$ fraction) is more pronounced in rock substrates.

Therefore, it is possible to count on the transition of phosphorus compounds from a brittle to an easily accessible form due to the processes of weathering of rocks and, in particular, the action of a biological factor (phytomelioration, etc.).

The results of estimation of the phosphorus potential buffer capacity changes in soil and rocks are shown in table 7.

Table 7

Potential buffer capacity of soil and rocks in relation to phosphorus

\begin{tabular}{|c|c|c|}
\hline Substrate & Plant melioration stage (1pms) & Q/I \\
\hline Black soil & One plant melioration stage & 0.025 \\
\hline Loess like loam & Quarry board & 0.06 \\
\hline Loess like loam & One plant melioration stage & 0.04 \\
\hline Red brown clay & Two plant melioration stages & 0.04 \\
\hline Gray green clay & One plant melioration stage & 0.04 \\
\hline
\end{tabular}

The results confirmed the effect of phytomelioration on the ability of rocks to absorb phosphorus compounds. Loess like loam plant melioration led to a decrease in the Q/I ratio to 0.04 even after one stage of plant melioration. The study of the rocks ability to absorb phosphorus allowed us to find that their biotic capacity increases under the influence of plant melioration.

Differences in the buffer capacity of plant meliorated rocks to the absorption of phosphorus to a certain extent associated with the $\mathrm{pH}$ level of the soil solution and the ratio of clay minerals. The results of estimating the direct potash reserve in soil and rocks are shown in figures 8 and 9.

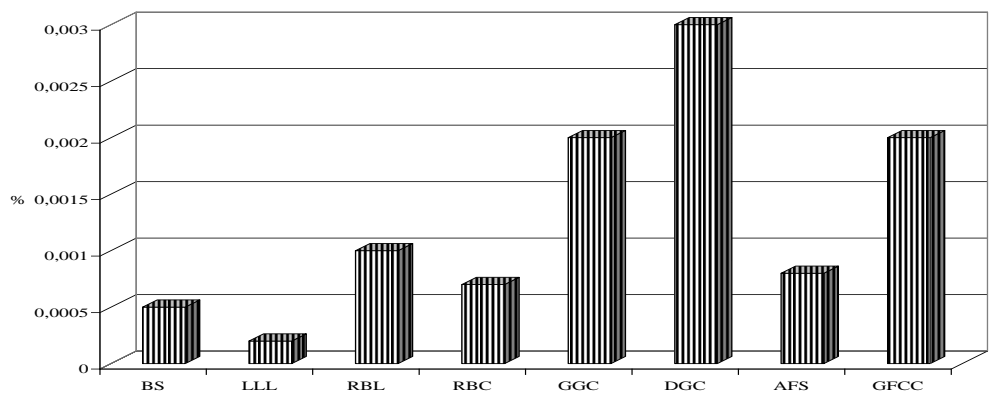

Fig. 8. The potassium content in aqueous extract of black soil and rocks, $\%$ 


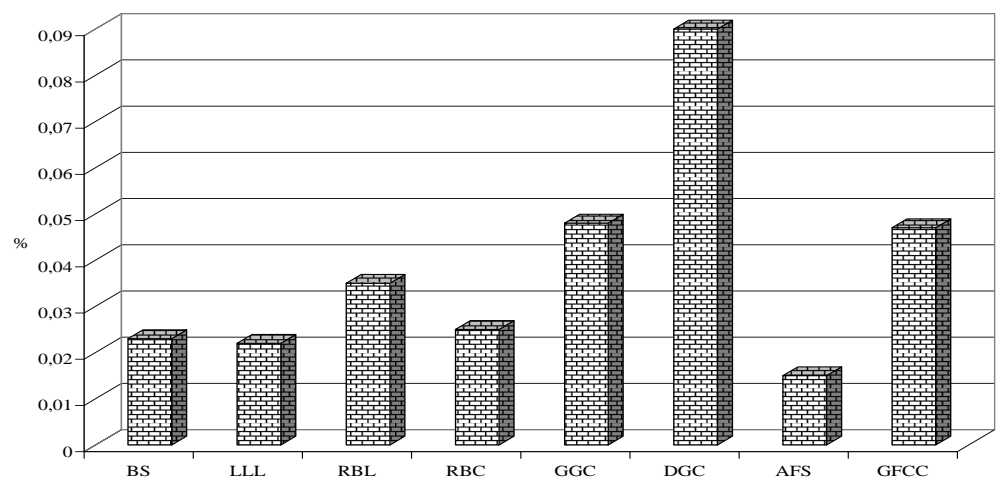

Fig. 9. Potassium content in buffer extract of black soil and rocks, \%

The concentration of potassium in the water extract is almost ten times less than in the ammonium-acetate extract. A comparative assessment showed that the potassium content in extracts from gray-green and dark-gray clays is 3-10 times higher than in other substrates.

Analysis of the initial information on the content of nutrients allowed us to draw some conclusions. The studied substrates have a low supply of nutrients, especially nitrogen, and partly phosphorus. Due to the fact that in loamy and clay soils, compared with sandy and sandy loam, the humification processes are more intensive, the studied rocks are more suitable as substrates for the accumulation of organic matter due to the thawing of the root remains of plants. Thus, the physical, chemical and biological properties of rock substrates determine both the potential and effective fertility of plant meliorated rocks.

\section{Assessment of the suitability of reclaimed land for production of apple fruits}

Heavy metals distribution along two main soil profiles filled with the black soil and loess like loam shown in the fig. 10 and fig. 11.

Comparison of the results revealed some differences in the distribution of heavy metals. The content of manganese in the profile of the loess like loam ranged from 60 to $160 \mathrm{mg} / \mathrm{kg}$ and was $2-4$ times less than the data for the black soil. The distribution of the other elements in the profile was almost identical.

The results of long-term field experiment with apple trees grafted on a low-growth M9 rootstock were analyzed both on growth and productivity indicators over four decades. Long-term observations allowed us to establish the duration of age periods: the period of growth and fruiting bearing is 3 years; fruiting is 6 years; fruiting and desiccation is 9 years; desiccation, 
fruiting and growth is 7 years; desiccation, growth and fruiting is 18 years. Apple trees began to bear fruit after four years of growth (Fig. 12).

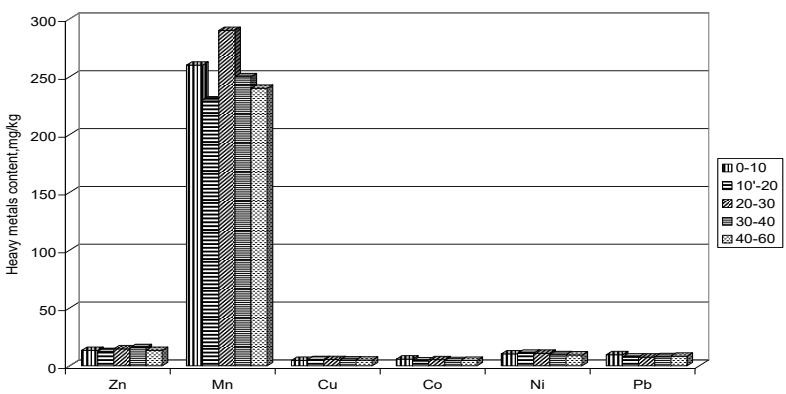

Fig. 10. Heavy metals distribution in the black soil profile

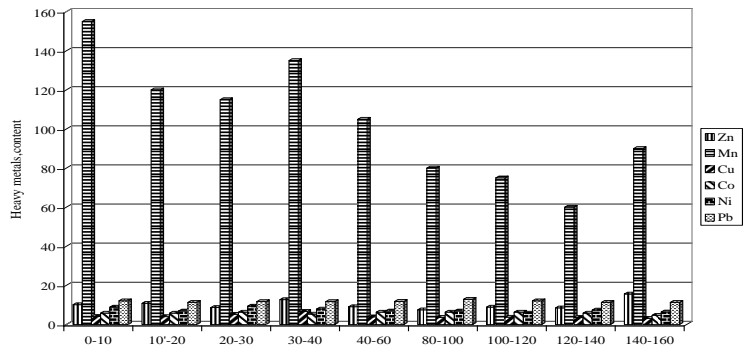

Fig. 11. Heavy metals distribution in the loess like loam profile

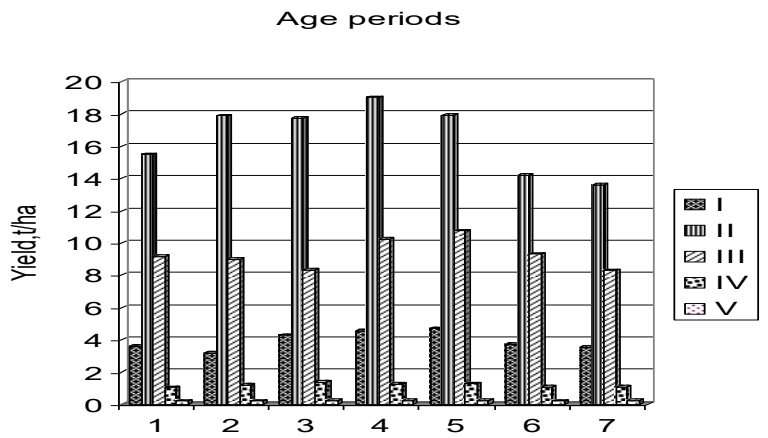

Fig. 12. Long-term dynamic of apple tree yield depending on the age period, $\mathrm{t} \mathrm{ha}^{-1}$ 
The maximum yield was obtained from 12-year-old trees and ranged from 20.35 to $28.2 \mathrm{t} \mathrm{ha}^{-1}$. Average yield of apple fruits in the first three periods ranged from 7.68 (and the variant with a forest-like loam) to $9.1 \mathrm{t} \mathrm{ha}^{-}$ ${ }^{1}$ (the third trial is black soil mass). High productivity of apple trees was observed for first two decades, and then sharply decreased.

The results of assessing the content of heavy metals in apple fruits in different trials of the experiment are shown in table 8.

Comparative analysis of the data shows that the content of heavy metals in apples does not exceed maximum permissible concentrations (MPC) regarding Ukrainian standards. The increased content of biological forms of iron in fruits was found in the trials $\mathrm{BS}, \mathrm{BS}+\mathrm{NPK}$ and $\mathrm{BS}+\mathrm{NPK}+$ manure. Meanwhile, this is half the maximum permissible concentrations $(50 \mathrm{mg} / \mathrm{kg}$ ). The concentration of copper in the fruit varied from 2.18 to $2.71 \mathrm{mg} / \mathrm{kg}$ and did not exceed MPC $5.0 \mathrm{mg} / \mathrm{kg}$. The amount of zinc in the apple fruit was in the range of $2.06-2.92 \mathrm{mg} / \mathrm{kg}$.

The highest content of manganese was fixed in the fruit samples in the $\mathrm{BS}+\mathrm{NPK}+$ manure trial.

Table 8

Heavy metal content in apple fruit, $\mathrm{mg} / \mathrm{kg}$

\begin{tabular}{|c|c|c|c|c|c|c|c|c|c|}
\hline Trial & $\mathbf{C o}$ & $\mathbf{N i}$ & $\mathbf{P b}$ & $\mathbf{M n}$ & $\mathbf{Z n}$ & $\mathbf{C u}$ & $\mathbf{F e}$ \\
\hline \multicolumn{7}{|c|}{ Pit: length $-1.4 \mathrm{~m}$; width $-1 \mathrm{~m}$; depth $-0.7 \mathrm{~m}$} \\
\hline LLL & trace & trace & trace & 3.18 & 2.06 & 2.71 & 15.0 \\
\hline BS(50\%)+LLL(50\%) & trace & trace & trace & 3.10 & 2.33 & 2.47 & 15.0 \\
\hline BS & trace & trace & trace & 3.18 & 2.08 & 2.47 & 21.25 \\
\hline BS+NPK & trace & trace & trace & 3.41 & 2.62 & 2.18 & 22.75 \\
\hline BS+NPK+manure & trace & trace & trace & 3.18 & 2.50 & 2.24 & 18.75 \\
\hline Pit: diameter-0.8 m; depth-1.0 m \\
\hline BS+ manure & trace & trace & trace & 2.83 & 1.67 & 2.59 & 15.0 \\
\hline BS+NPK+manure & trace & trace & trace & 4.10 & 2.92 & 2.71 & 12.5 \\
\hline
\end{tabular}

Note: *-loess like loam (LLL); the black soil (BS)

The amount of lead, nickel, and cobalt was found in trace amounts. The possibility of organic production of apple fruits on the studied trials with black soil enriched with manure was established. It is known that depending on the type of rootstock, fruit trees with weak, medium and strong growth rates are distinguished. The speed of growth determines the age of the garden. Fruit trees on dwarf rootstocks produce fruits up to 15-20 years. The life cycle of apple tree on MM106 rootstock is from 30 to 35 years. The garden was lauded on strong-growing rootstock can produce fruits up to 80-100 years. It is obvious that the age of the laid garden needs to be uprooted. A comparative assessment of the wood energetic value was conducted to see the prospects to use it as fuel briquettes. Wood samples were taken from two orchards planted on rootstocks with a weak (M9) and medium (MM106) growth rate. The wood age from the orchard laid on the 
M9 rootstock was 15 years. The age of wood from the garden laid on the rootstock MM106 was 40 years. The results of thermogravimetric assessment of biomass of wood samples of apple trees from two orchards with different types of rootstock are shown in figures 13-15.

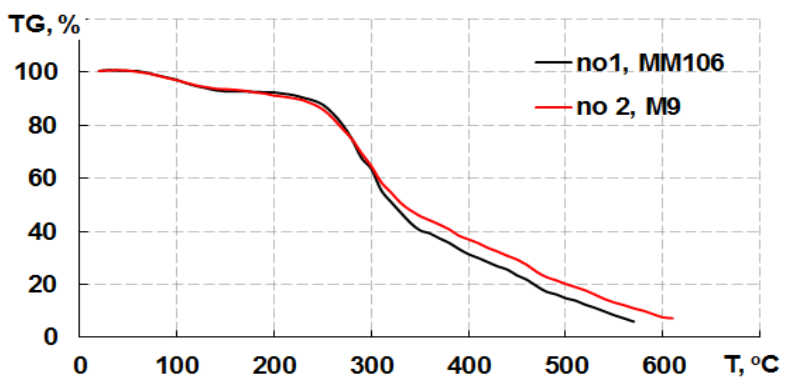

Fig. 13. Estimation of mass loss during heating

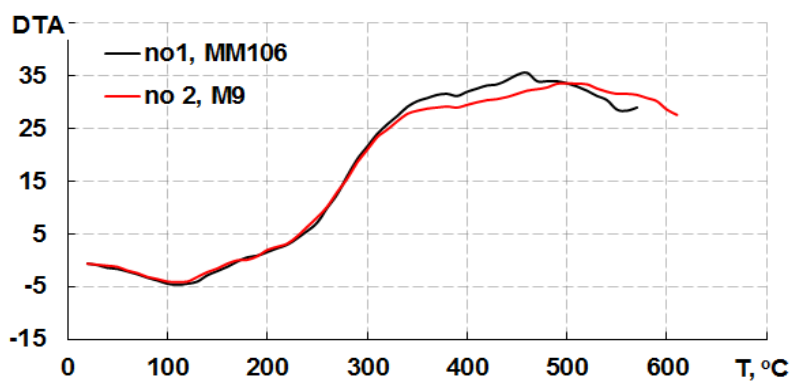

Fig. 14. Differential thermal analysis of biomass

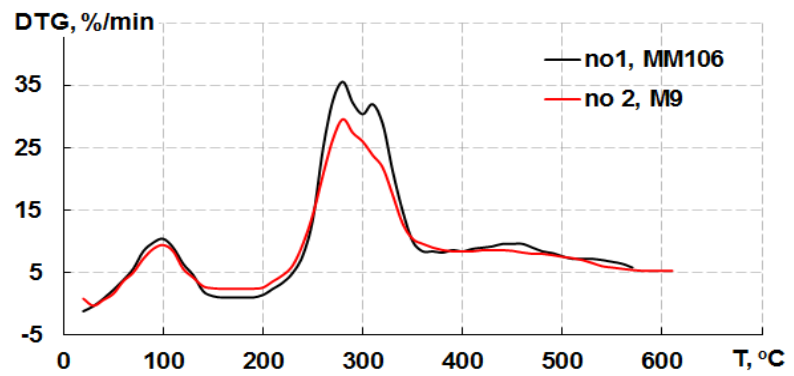

Fig. 15. Estimation of the rate of combustion of biomass during heating 
Three stages of wood combustion for samples at the age of 15 and 40 years can be distinguished according to the thermogravimetric analysis (Fig. 6-8). The first stage takes place within the temperature range of $40-150^{\circ} \mathrm{C}$. The second stage continues in the temperature range of $200-370^{\circ} \mathrm{C}$. This stage is characterized by the highest speed of combustion. The third stage takes place within the temperature range of $375-550^{\circ} \mathrm{C}$. A higher DTG value was observed in the biomass sample no. 1 at the age of 40 years. So, the wood of apple fruit trees with an average growth rate (rootstock MM106) at the age of 40 years can be used with the best energy effect on fuel briquettes after uprooting the orchard.

\section{Soil amendments effect on Miscanthus and Switchgrass growth, heavy metals uptake and thermal parameters of biomass}

In the first year after planting, Miscanthus and Switchgrass were actively growing, increasing aboveground and underground biomass. At the end of the growth season, the height of the plants reached about $1 \mathrm{~m}$, and the average shoot density was 72.5 (Switchgrass) and 18.1 pieces per $\mathrm{m}^{2}$ (Miscanthus). The prolonged drought of 2017 did not allow plants to grow well enough (Fig. 16). As a result, in the second vegetation season, their height has not changed much. Nevertheless, the formation of new orthotropic shoots continued, which made it possible to achieve a yield of aboveground biomass at the level of 4.3 (Switchgrass) and 5.04 tons per hectare (Miscanthus), respectively.

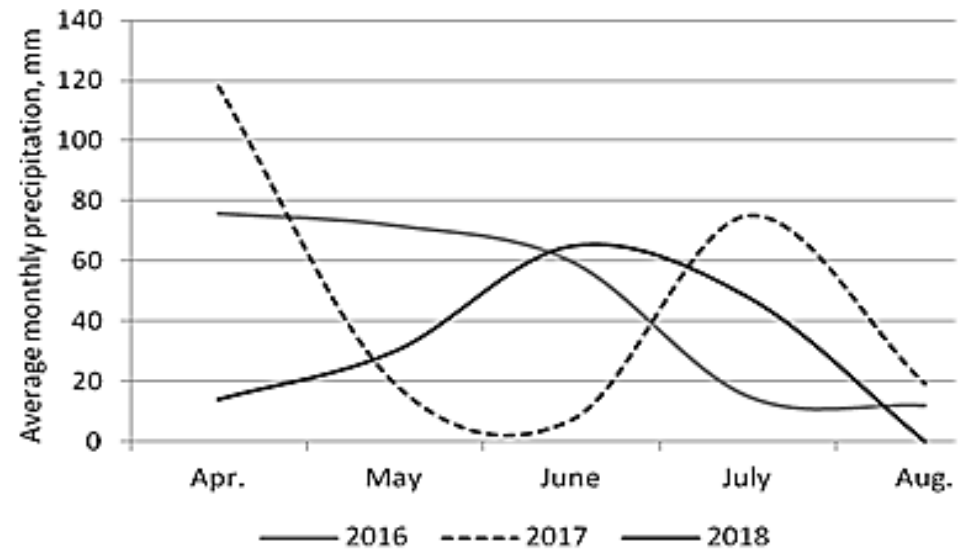

Fig. 16. Average monthly precipitation during the growing period for years of research 
The data from the two-year studies presented in our previous publications $^{20,21}$ showed that addition of the amendments to the substrate positively affected morphometric parameters and biomass productivity. So, for Switchgrass, in the first year of cultivation the plant height increased by $5 \%$ through the applying mineral fertilizers and by $9.5 \%$ in the case of sewage sludge addition. The greatest effect was observed from addition ash and a double dose of sludge when the growth rate increased by $14.3 \%$. In the second year, additional fertilizing has improved studied parameter from $10 \%$ (ash) to $25.6 \%$ (sewage sludge). The greatest influence $(41.3 \%$ ) was observed through the double dose of sewage sludge application. At the same time, biomass productivity has increased from $8.2 \%$ (ash) to $99.3 \%$ (double dose of sludge).

According to the data obtained in the experiment with Miscanthus, the greatest effect was observed for plants grown on the soil with the mineral fertilizers addition, while the application of ash showed the minimal increasing of the growth parameters. As result, when ash was added, the biomass yield increased only by $6.5 \%$ compared to the control, while the addition of mineral fertilizer and sewage sludge increased the biomass yield by 2-2.3 times. Thus, the Miscanthus productivity in the second year of vegetation on these plots was $11.6 \mathrm{t} \mathrm{DM} \mathrm{ha}^{-1}$ and $11.9 \mathrm{t} \mathrm{DM} \mathrm{ha}^{-1}$, respectively. It is known that both Miscanthus and Switchgrass generally reach full productivity by the end of the third year of cultivation ${ }^{22,23}$. Depending on the conditions, the average biomass yield in this period is 8-14 $\mathrm{t}$ DM $\mathrm{ha}^{-1}$ for Switchgrass and 10-30 $\mathrm{t} \mathrm{DM} \mathrm{ha}^{-1}$ for Miscanthus ${ }^{24,25,26,27,28}$. Usually, on the reclaimed lands productivity is lower

${ }^{20}$ Kharytonov M.M., Babenko M.G., Martynova N.V., Rula I.V., Klimkina I.I. 2018. Bioenergetic potential of switchgrass and sweet sorghum on the reclaimed lands. Development of natural sciences in countries of the European Union taking into account the challenges of XXI century: Collective monograph. Lublin : Izbevieciba "Baltija Publishing". 2018. P. 453-474.

${ }^{21}$ Kharytonov M., Pidlisnyuk V., Stefanovska T., Babenko M., Martynova N., Rula I. The estimation of Miscanthus $\times$ giganteus adaptive potential for cultivation on the mining and post-mining lands in Ukraine. Environment Science and Pollution Research. 2019. Vol.26 (3). P. 2974-2986. https://doi.org/10.1007/s11356-018-3741-0

${ }_{22}$ Clifton-Brown J.C, Lewandowski I. Water-use efficiency and biomass partitioning of three different Miscanthus genotypes with limited and unlimited water supply. Ann. Bot. 2000. Vol. 86(1). P. 191-200. https://doi.org/10.1006/anbo.2000.1183

${ }^{23}$ Burli P. Forgoston E., Lal P., Billings L., Wolde B. Adoption of switchgrass cultivation for biofuel under uncertainty: A discrete-time modeling approach. Biomass and Bioenergy. 2017. Vol. 105. P. 107-115. http://dx.doi.org/10.1016/j.biombioe.2017.06.012

${ }^{24}$ Fike J.H., Parrish D.J., Wolf D.D., Balasko J.A., Green J.T., Rasnake M., Reynolds J.H. Long-term yield potential of switchgrass-for-biofuel systems. Biomass and Bioenergy. 2006. Vol. 30(3). P. 198-206. https://doi.org/10.1016/j.biombioe.2005.10.006

${ }^{25}$ Wullschleger S.D., Davis E.B., Borsuk M.E., Gunderson C.A., Lynd L.R. Biomass Production in Switchgrass across the United States: Database Description and Determinants of Yield. Agronomy Journal. 2010. Vol. 102(4). P. 1158-1168. https://doi.org/10.2134/agronj2010.0087 
and, as a rule, does not exceed 5-6.5 $\mathrm{t} \mathrm{DM} \mathrm{ha}^{-1}$ for Switchgrass and 7-11 t DM ha ${ }^{-1}$ for Giant Miscanthus ${ }^{29,30,31}$. As a rule, Miscanthus has more growth power than Switchgrass.

However, under conditions of poor fertility and insufficient water supply, it could not provide decent competition. As a result, the canopy height of both plant species in the control plots was almost the same, $131.1-131.5 \mathrm{~cm}$. The application of amendments led to an increase in the parameters of vertical and horizontal growth from $2 \%$ to $40 \%$ (Fig. 14). The use of ash had the least effect, and the influence of double dose of sewage sludge was the strongest. The thickness of the shoots has also increased. In Switchgrass, the stem diameter under the influence of ash and a mixture of ash and sludge changed slightly, up to 5\%. The application of sewage sludge and mineral fertilizer increased this indicator by 11-18\%. In Miscanthus, only a double dose of sludge had an improving effect (13.9\%), other amendments did not have a significant impact (1-1.6\%). In this way, the response of Switchgrass plants to amendment application was better than Miscanthus, which contributed to an increase in biomass yield from $7 \mathrm{t} \mathrm{DM} \mathrm{ha}^{-1}$ (control) to 15-17 t DM ha ${ }^{-1}$ (sewage sludge). In Miscanthus, the maximum yield $\left(12.4-13.3 \mathrm{t} \mathrm{DM} \mathrm{ha}^{-1}\right)$ was achieved using mineral fertilizer and double dose of sludge (Fig. 17). Thus, for Switchgrass, the most promising amendment is only sewage sludge. For Miscanthus, the use of sewage sludge in amount of $10-20 \mathrm{t} \mathrm{ha}^{-1}$ and mineral fertilizers is optimal.

${ }^{26}$ Anderson E. Arundale R., Maughan M., Olandeinde A., Wycislo A., Voigt T. Growth and agronomy of Miscanthus $\times$ giganteus for biomass production. Biofuels. 2011. Vol. 2(1). P. 71-87. https://doi.org/10.4155/bfs.10.80

${ }^{27}$ Mitchell R., Vogel K., Kenneth P., Uden D.R. The feasibility of switchgrass for biofuel production. Biofuels. 2012. Vol.3(2). P. 47-59. http://digitalcommons.unl.edu/ ncfwrustaff/169

${ }^{28}$ Kalinina O., Nunn Ch., Sanderson R., Hastings A.F.S., Weijde T., Özgüven M., Tarakanov I., Schüle H., Trinidade L.M., Dolstra O., Schwarz K., Iqbal Y., Kiesel A., Mos M., Lewandowski I., Clifton-Brown J.C. Extending Miscanthus cultivation with Novel Germaplasm at six contrasting sites. Frontiers in Plant Science. 2017. Vol. 8. P. 1-15. https://doi.org/10.3389/fpls.2017.00563

${ }_{29}$ Marra M., Keene T., Skousen J., Griggs T. Switchgrass yield on reclaimed surface mines for bioenergy production. J. Environ. Qual. 2013. Vol.42(3).P. 696-703. doi: $10.2134 /$ jeq2012.0453

${ }^{30}$ Scagline S., Skousen J., Griggs T. Switchgrass and miscanthus yields on reclaimed surface mines for bioenergy production. Journal American Society of Mining and Reclamation. 2015. Vol. 4(2). P. 80-90. http://doi.org/10.21000/JASMR15020080

${ }^{31}$ Cherney J.H., Cherney D.J.R., Paddock K.M. Biomass Yield and Composition of Switchgrass Bales on Marginal Land as Influenced by Harvest Management Scheme. Bioenergy Research. 2018. Vol. 11(1). P. 34-43. https://doi.org/ 10.1007/s12155-0179875-y 

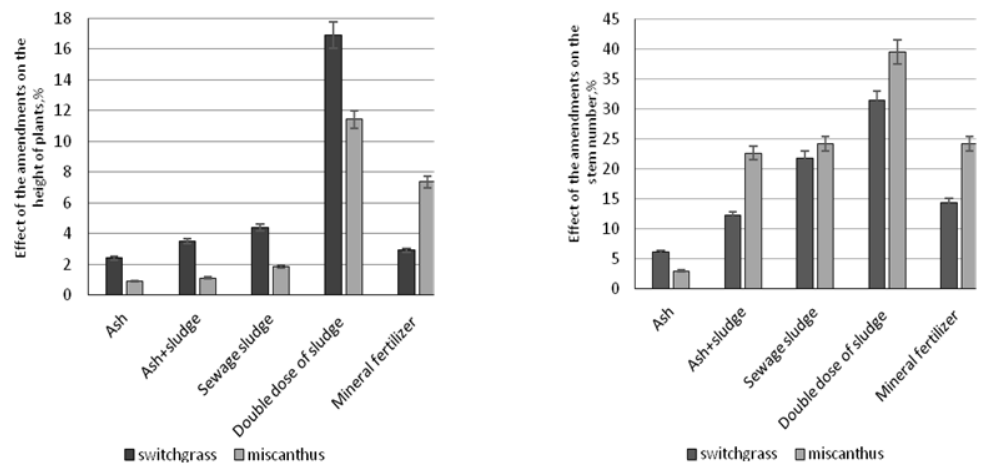

a)
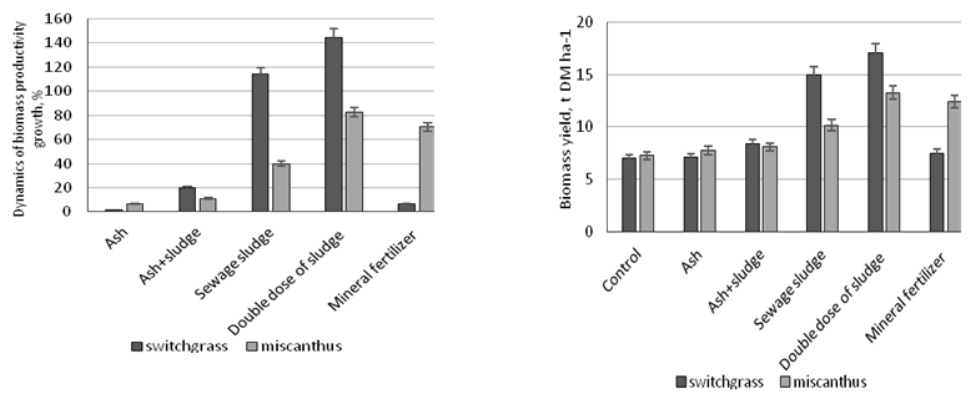

b)

Fig. 17. Effect of the amendments on the growth parameters of 3-year-old plants of Switchgrass and Miscanthus, \% (a) and effect of the amendments on the biomass yield of 3-year-old plants of Switchgrass and Miscanthus grown on reclaimed lands $(b)$

Switchgrass and Miscanthus are promising potential agents for long-term remediation of soils contaminated with heavy metals ${ }^{32,33}$. In turn, various

${ }^{32}$ Zhang Ch., Guo J., Lee D.K., Anderson E., Huang H. Growth responses and accumulation of cadmium in switchgrass (Panicumvirgatum L.) and prairie cordgrass (Spartinapectinata Link). RSC Advances. 2015. Vol. 102 (5). P. 83700-83706. https://doi.org/10.1039/C5RA13073E

Korzeniowska J., Stanislawska-Glubiak E. Phytoremediation potential of Miscanthus $\times$ giganteus and Spartina pectinata in soil contaminated with heavy metals. Environmental Science and Pollution Research. 2015. Vol. 22(15). P. 11648-11657. https://doi.org/10.1007/s11356-015-4439-1 
amendments can affect the absorption capacity of plants, increasing or decreasing the heavy metals uptake ${ }^{34,35,36,37,38}$.

In our experiment, the content of $\mathrm{Mn}$ and $\mathrm{Fe}$ was the highest in plant biomass (Table 9). In the control plot, the content of heavy metals in the biomass of Miscanthus was higher than in Switchgrass by $20-30 \%$. On the plots with amendments, the content of $\mathrm{Mn}$ and $\mathrm{Zn}$ was also higher in Miscanthus. At the same time, $\mathrm{Cu}$ and $\mathrm{Pb}$ accumulated more intensively in Switchgrass biomass. It was detected that the amendment application modified the physicochemical properties of soil, thereby enhancing the availability of heavy metals in the soil and increasing their accumulation in biomass (Fig. 18).

The mineral fertilizer use had the least effect (from $0.1 \%$ to $90 \%$ for Miscanthus and from $32 \%$ to $48 \%$ for Switchgrass). The addition of double dose of sewage sludge had the most significant effect and caused an increase in content of heavy metals by $90-165 \%$ for Miscanthus and by $124-333 \%$ for Switchgrass compared to the control. It was detected during analyzing heavy metals content in the Miscanthus biomass that amendments affect Mn accumulation most intensively. Greatest effect was noted for $\mathrm{Cu}$ in the Switchgrass biomass.

The application of the amendments led to an increase in heavy metal uptake by the Miscanthus and Switchgrass biomass (Fig. 19).

In control, the level of heavy metals uptake was higher in Miscanthus compared to Switchgrass. The introduction of amendments has changed this ratio. The introduction of mineral fertilizers, ash and mixture of ash and sewage sludge contributed to an increase in the uptake of $\mathrm{Zn}, \mathrm{Cu}$ and $\mathrm{Pb}$ by the biomass of both plant species on average 1.5-2.6 times.

${ }^{34}$ Castaldi P., Santona L., Melis P.2005. Heavy metal immobilization by chemical amendments in a polluted soil and influence on white lupin growth. Chemosphere. Vol. 60(3). P. 365-371. https://doi.org/10.1016/j.chemosphere.2004.11.098

${ }^{35}$ Singh R.P., Agrawal M. Variations in heavy metal accumulation, growth and yield of rice plants grown at different sewage sludge amendment rates. Ecotoxicology and Environmental Safety. 2010. Vol. 73 (4). P. 632-641.https://doi.org/10.1016/ j.ecoenv.2010.01.020

${ }^{36}$ Pavel P.B., Puschenreiter M., Wenzel W.W., Diacu E., Barbu C.H. Aided phytostabilization using Miscanthus sinensis $\times$ giganteus on heavy metal-contaminated soils. Science of The Total Environment. 2014. Vol. 479-480. P. 125-131. https://doi.org/10.1016/j.scitotenv.2014.01.097

Zhou H., Zhou X., Zeng M., Liao B.H., Liu L., Yang W.T., Wu Y.M., Qiu .Y., Wang Y.J. Effects of combined amendments on heavy metal accumulation in rice (Oryza sativa L.) planted on contaminated paddy soil. Ecotoxicology and Environmental Safety. 2014. Vol. 101. P. 226-232. https://doi.org/10.1016/j.ecoenv.2014.01.001

${ }^{38}$ Antonkiewicz J., Pełka R., Bik-Małodzińska M., Żukowska G.,Gleń-Karolczyk K. The effect of cellulose production waste and municipal sewage sludge on biomass and heavy metal uptake by a plant mixture. Environmental Science and Pollution Research. 2018. Vol. 25. P. 31101-31112. https://doi.org/10.1007/s11356-018-3109-5 
Table 9

Heavy metals content in the biomass

of Miscanthus and Switchgrass, $\mathrm{mg} \mathrm{kg}^{-1}$

\begin{tabular}{|c|c|c|c|c|c|c|}
\hline Metal & Control & Ash & $\begin{array}{c}\text { Ash }+ \\
\text { sludge }\end{array}$ & $\begin{array}{c}\text { Sewage } \\
\text { sludge }\end{array}$ & $\begin{array}{c}\text { Double } \\
\text { dose of } \\
\text { sludge }\end{array}$ & $\begin{array}{c}\text { Mineral } \\
\text { fertilizer }\end{array}$ \\
\hline \multicolumn{7}{|c|}{ Miscanthus } \\
\hline $\mathrm{Fe}$ & $159.9 \pm 1.22$ & $246.7 \pm 0.92$ & $250.7 \pm 1.04$ & $242.5 \pm 0.87$ & $262.7 \pm 1.19$ & $179.6 \pm 0.85$ \\
\hline $\mathrm{Mn}$ & $62.0 \pm 0.36$ & $142.5 \pm 0.91$ & $151.3 \pm 1.12$ & $138.6 \pm 1.53$ & $163.5 \pm 1.71$ & $118,1 \pm 0.98$ \\
\hline $\mathrm{Zn}$ & $14.6 \pm 0.26$ & $26.0 \pm 0.25$ & $27.4 \pm 0.23$ & $24.0 \pm 0.26$ & $29.3 \pm 0.22$ & $18.0 \pm 0.26$ \\
\hline $\mathrm{Cu}$ & $5.4 \pm 0.11$ & $7.8 \pm 0.15$ & $8.8 \pm 0.17$ & $8.6 \pm 0.21$ & $14.3 \pm 0.23$ & $6.3 \pm 0.11$ \\
\hline $\mathrm{Pb}$ & $6.4 \pm 0.18$ & $8.4 \pm 0.12$ & $9.2 \pm 0.15$ & $10.4 \pm 0.26$ & $12.1 \pm 0.11$ & $6.4 \pm 0.11$ \\
\hline \multicolumn{7}{|c|}{ Switchgrass } \\
\hline $\mathrm{Fe}$ & $129.5 \pm 0.74$ & $181.0 \pm 0.93$ & $211.0 \pm 1.20$ & $205.1 \pm 1.25$ & $250.0 \pm 1.51$ & $195.0 \pm 0.64$ \\
\hline $\mathrm{Mn}$ & $49.5 \pm 0.56$ & $78.3 \pm 0.59$ & $83.5 \pm 0.71$ & $84,8 \pm 0.91$ & $112.0 \pm 1.28$ & $67.6 \pm 0.78$ \\
\hline $\mathrm{Zn}$ & $11.0 \pm 0.17$ & $16.0 \pm 0.26$ & $17.3 \pm 0.20$ & $19.0 \pm 0.26$ & $24.6 \pm 0.32$ & $14.5 \pm 0.21$ \\
\hline $\mathrm{Cu}$ & $4.2 \pm 0.11$ & $8.4 \pm 0.23$ & $9.1 \pm 0.15$ & $7.8 \pm 0.15$ & $18.2 \pm 0.15$ & $6.2 \pm 0.06$ \\
\hline $\mathrm{Pb}$ & $4.5 \pm 0.11$ & $8.6 \pm 0.17$ & $8.3 \pm 0.11$ & $11.0 \pm 0.17$ & $14.2 \pm 0.21$ & $6.4 \pm 0.10$ \\
\hline
\end{tabular}

Miscanthus

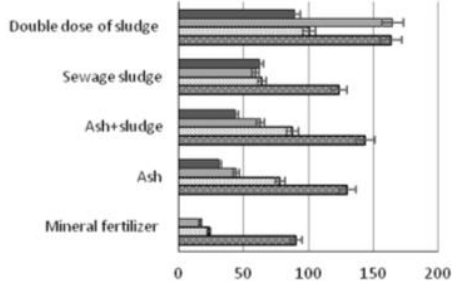

마 $\square \mathrm{Cu} \square \mathrm{Zn} \square \mathrm{Mn}$
Switchgrass

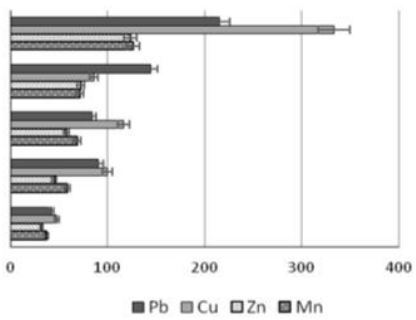

Fig. 18. The effect of the amendments applying on the content of heavy metals in plant biomass, $\%$

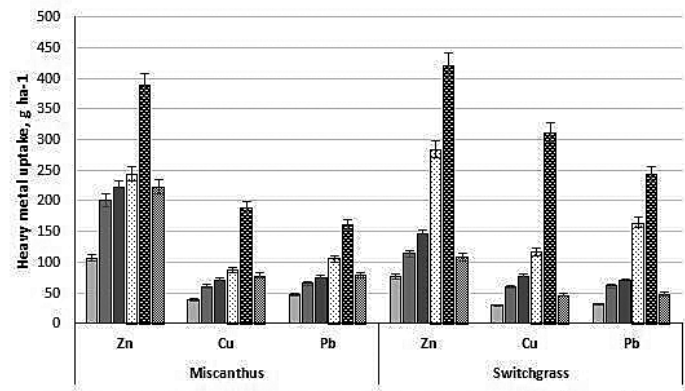

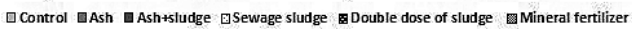

Fig. 19. Heavy metal uptake $(\mathrm{Cu}, \mathrm{Zn}$ and $\mathrm{Pb})$ by the 3-year-old plants of Miscanthus and Switchgrass 
The application of single dose of sewage sludge enhanced the uptake of these metals by the Miscanthus 2.2-2.7 times, whereas for Switchgrass the uptake level increased 3.7-5.2 times. The applying of double dose of sewage sludge had the greatest effect. However, while in Miscanthus the uptake capacity was increased by 3.4-4.8 times, in Switchgrass it was augment by $5.5(\mathrm{Zn}), 7.7(\mathrm{~Pb})$ and $10.6(\mathrm{Cu})$ times.

It was also found that sewage sludge significantly influences the Fe accumulation in Switchgrass biomass. As a result, Fe uptake by the 3 -year-old Switchgrass plants amounted to $3068.8-4280.0 \mathrm{~g} \mathrm{ha}^{-1}$, which is 23-24\% more compared to Miscanthus (Fig. 20).

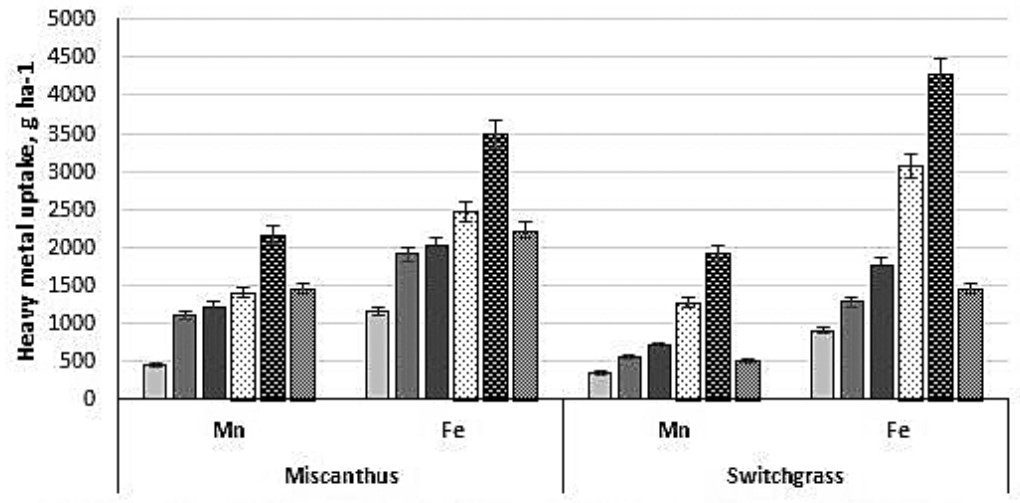

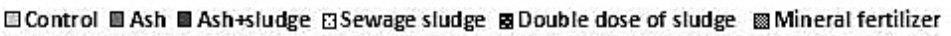

Fig. 20. Heavy metal uptake (Mn and Fe) by the 3-year-old plants of Miscanthus and Switchgrass

Thermogravimetric analysis showed that the decomposition of the biomass of both studied species occurs in two periods (Table 10). The first period consists of one stage of decomposition of volatile components and evaporation of water. The second period consists of three stages: the disruption of hemicellulose, the destruction of cellulose and lignin, and the completion of the lignin decomposition and carbonate residue burning. It was noted that the first stage of the Switchgrass biomass destruction was longer and the percent of weight loss was greater (by $7.4 \%$ in stems and by $30.9 \%$ in leaf biomass).

A lower content of volatile components and water was characteristic of stem biomass of both species. The stage of hemicellulose decomposition in the Switchgrass biomass was more active. The reaction rates in the leaves and stems were higher by $22.8 \%$ and $15.7 \%$, respectively. At the same time, the destruction of cellulose and lignin was more intense in the Miscanthus biomass. More complete biomass combustion was observed in Switchgrass. 
The share of residual mass in Switchgrass was $7.6 \%$ (leaves) and $4.8 \%$ (stems), and in Miscanthus 9.55\% (leaves) and 5.67\% (stems). The application of soil amendments has led to changes in the thermal characteristics of plant biomass. So, in the leaf Miscanthus biomass, the amount of volatile components decreased from $14.6 \%$ (variant with a double dose of sludge) to $22.8 \%$ (variant with ash). In addition, the first stage of thermolysis took place at higher temperatures.

Table 10

Thermal decomposition of Miscanthus and Switchgrass biomass

\begin{tabular}{|c|c|c|c|c|c|c|c|c|}
\hline \multicolumn{9}{|c|}{ Leaves } \\
\hline \multirow[b]{2}{*}{ Stage } & \multicolumn{4}{|c|}{ Miscanthus } & \multicolumn{4}{|c|}{ Switchgrass } \\
\hline & $\begin{array}{c}\text { Interval, } \\
{ }^{\circ} \mathrm{C}\end{array}$ & $\begin{array}{l}\text { Extremu } \\
\mathrm{m} \text { point, } \\
{ }^{\circ} \mathrm{C}\end{array}$ & $\begin{array}{c}\text { Maximu } \\
\text { m rate, } \\
\% / \text { min }\end{array}$ & $\begin{array}{l}\text { Weight } \\
\text { loss, } \%\end{array}$ & $\begin{array}{c}\text { Interval } \\
,{ }^{\circ} \mathrm{C}\end{array}$ & $\begin{array}{l}\text { Extremu } \\
\text { m point, } \\
{ }^{\circ} \mathrm{C}\end{array}$ & $\begin{array}{c}\text { Maximu } \\
\text { m rate, } \\
\% / \text { min }\end{array}$ & $\begin{array}{l}\text { Weight } \\
\text { loss, } \%\end{array}$ \\
\hline I & $50-160$ & 90 & 8.8 & 7.03 & $30-170$ & 80 & 8.6 & 9.2 \\
\hline II & $160-280$ & 260 & 24.6 & 22.72 & $\begin{array}{c}170-29 \\
0\end{array}$ & 270 & 30.2 & 28.8 \\
\hline III & $280-380$ & 300 & 32.4 & 33.36 & $\begin{array}{c}290-37 \\
0\end{array}$ & 300 & 31.6 & 25.8 \\
\hline IV & $380-540$ & 420 & 10.6 & 27.34 & $\begin{array}{c}370-55 \\
0\end{array}$ & 420 & 9.4 & 28.6 \\
\hline \multicolumn{9}{|c|}{ Stems } \\
\hline \multicolumn{9}{|c|}{ Miscanthus } \\
\hline Stage & $\begin{array}{c}\text { Interval, } \\
{ }^{\circ} \mathrm{C}\end{array}$ & $\begin{array}{l}\text { Extremu } \\
\text { m point, } \\
{ }^{\circ} \mathrm{C}\end{array}$ & $\begin{array}{c}\text { Maximu } \\
\text { m rate, } \\
\% / \text { min }\end{array}$ & $\begin{array}{l}\text { Weight } \\
\text { loss, } \%\end{array}$ & $\begin{array}{c}\text { Interval } \\
,{ }^{\circ} \mathrm{C}\end{array}$ & $\begin{array}{l}\text { Extremu } \\
\text { m point, } \\
{ }^{\circ} \mathrm{C}\end{array}$ & $\begin{array}{c}\text { Maximu } \\
\text { m rate, } \\
\% / \text { min }\end{array}$ & $\begin{array}{l}\text { Weight } \\
\text { loss, \% }\end{array}$ \\
\hline $\mathrm{I}$ & $60-150$ & 100 & 8.0 & 5.66 & $50-170$ & 100 & 7.4 & 6.08 \\
\hline II & $\begin{array}{c}150- \\
-280\end{array}$ & 270 & 26.8 & 26.66 & $\begin{array}{c}170-29 \\
0\end{array}$ & 270 & 31.0 & 33.92 \\
\hline III & $\begin{array}{c}280-40 \\
0\end{array}$ & 300 & 29.0 & 37.57 & $\begin{array}{c}290-35 \\
0\end{array}$ & 300 & 25.6 & 22.0 \\
\hline IV & $\begin{array}{c}400-58 \\
0\end{array}$ & 430 & 9.2 & 24.44 & $\begin{array}{c}350-57 \\
0\end{array}$ & 420 & 7.0 & 33.2 \\
\hline
\end{tabular}

The hemicellulose degradation interval has also shifted to higher temperatures region. As a result, the peak of this component decomposition was almost veiled by the peak of destruction of cellulose, which can be clearly seen on the DTG curves (Fig. 21).

The rate of passage of the fourth stage was 2-4 times lower compared to the control, and the share of unburned residue increased by $21-65 \%$. Moreover in variants with amendments, the magnitude of the thermal effect was lower at almost all stages of decomposition (Fig. 22). 
Switchgrass
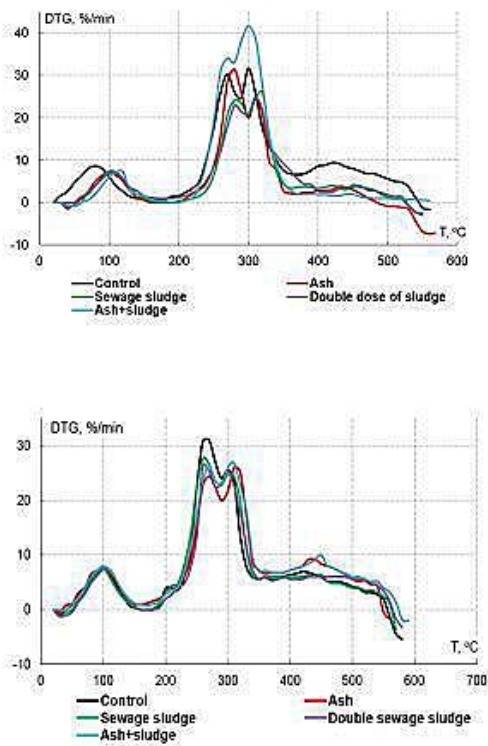

Miscanthus

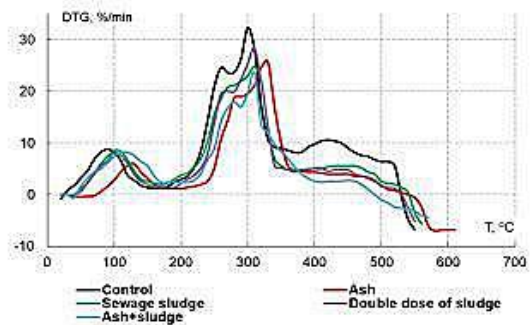

Leaves

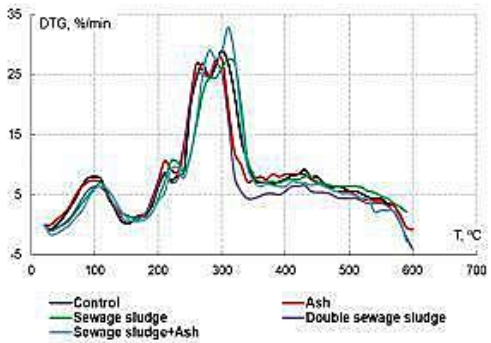

Stems

Fig. 21. DTG curves of the thermal decomposition of Switchgrass and Miscanthus biomass

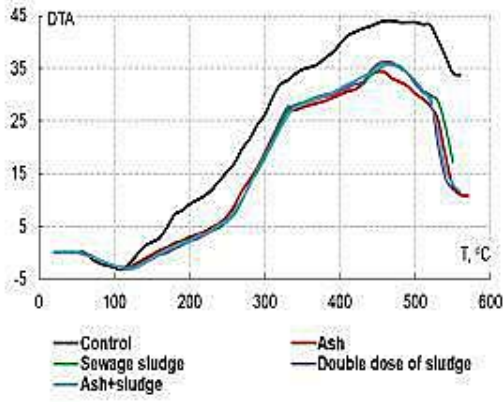

Switchgrass

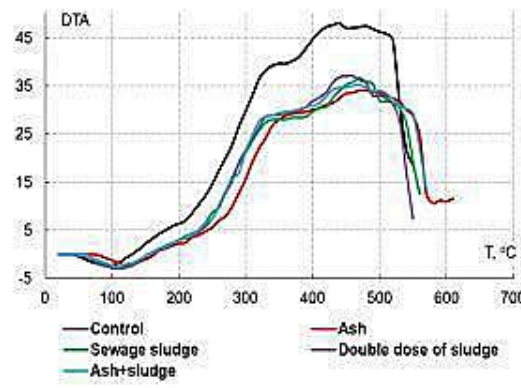

Miscanthus

Fig. 22. DTA curves of the thermal decomposition of Switchgrass and Miscanthus leaf biomass

The destruction of hemicellulose and cellulose passed more active by $8-13 \%$ only in the ash + sludge variant. As in the case of leaf biomass, a 
tendency to increase the amount of unburned residue also took place. However, the increase in ash content was small, in the range of $2.3-14.1 \%$. The application of sunflower husk ash increased the value of this parameter by $32.9 \%$. Under the influence of soil amendments, the content of water and volatile components decreased by $17.4-37.0 \%$ in the leaf biomass of Switchgrass. The process rates of the first stage were lower. The decomposition of hemicellulose proceeded slower by $22.5-24.5 \%$ in variants with sewage sludge. The variants "ash" and "ash + sludge", on the contrary, was faster by $4.0-12.6 \%$. The destruction of cellulose by the simultaneous addition of ash and sewage sludge also occurred much faster (by $31.6-70.5 \%)$ than in the control and other variants of the experiment. In all experimental variants, the lignin decomposition process was 2.2-4.7 times slower than in the control, and share of residual mass increased by $50.0-73.7 \%$. Similarly to Miscanthus, the magnitude of the thermal effect of the control samples was higher. The first stage of thermolysis in stem Switchgrass biomass took place in a similar way in all experiment variants, and the content of volatile components decreased by $7.2-20.0 \%$. The destruction of hemicellulose slowed down in biomass grown on plots with amendments. There were no particular differences in the stages of cellulose and lignin decomposition among the experimental and control options. The amount of unburned residue considerably increased (by 50-60\%) only in the variants of "ash" and "ash + sludge". According to the activation energy data, the biomass of Switchgrass grown without amendments (control) has greater thermal stability than Miscanthus biomass (Table 11). The addition of ash led to an increase in the thermal stability of the Miscanthus leaf biomass at the initial stage of destruction by $39.5 \%$ and at the stage of main components decomposition by $18.7 \%$.

The effect of other amendments was insignificant. In stem biomass, thermal stability at the initial stage increased by $25 \%$ with a single dose of sewage sludge and decreased by $20 \%$ with ash. In other variants, the changes were within $14 \%$. The influence of amendments on the thermal stability of stem biomass during the decomposition of the main components was not detected. The adding of a single, double dose of sewage sludge and a combination of sludge and ash increased the thermal stability of Switchgrass leaf biomass at the initial stage of thermolysis by $28.4 \%, 40.2 \%$ and $31.9 \%$.

The values of activation energy at the stage of decomposition of the main components have not changed significantly. The use of amendments (except for a double dose of sludge) led to a significant decrease in the thermal stability of stem biomass at the initial stage of decomposition. The difference was $33.4-41.0 \%$. Changes in this parameter during the destruction of the main components did not exceed $8 \%$. 
Activation energy of Miscanthus

and Switchgrass biomass thermal decomposition

\begin{tabular}{|c|c|c|c|c|}
\hline \multirow{2}{*}{ Experiment variant } & \multicolumn{2}{|c|}{ Leaves } & \multicolumn{2}{c|}{ Stems } \\
\cline { 2 - 5 } & \multicolumn{2}{|c|}{ Activation energy, kJ/mol } & \multicolumn{2}{c|}{ Activation energy, kJ/mol } \\
\cline { 2 - 5 } & Initial & $\begin{array}{c}\text { Main } \\
\text { components }\end{array}$ & Initial & $\begin{array}{c}\text { Main } \\
\text { components }\end{array}$ \\
\hline \multicolumn{5}{|c|}{ Miscanthus: } \\
\hline Control & 49.56 & 48.43 & 54.03 & 46.81 \\
\hline Ash & 69.13 & 57.49 & 43.34 & 42.78 \\
\hline Sewage sludge & 43.78 & 49.40 & 67.46 & 46.74 \\
\hline $\begin{array}{c}\text { Double dose of } \\
\text { sludge }\end{array}$ & 47.29 & 50.77 & 46.73 & 46.74 \\
\hline Ash+sludge & 51.93 & 53.01 & 61.87 & 52.50 \\
\hline \multicolumn{5}{|c|}{ Switchgrass: } \\
\hline Control & 55.28 & 51.23 & 78.39 & 52.90 \\
\hline Ash & 56.92 & 54.94 & 49.82 & 54.95 \\
\hline Sewage sludge & 71.00 & 58.04 & 46.23 & 48.45 \\
\hline $\begin{array}{c}\text { Double dose of } \\
\text { sludge }\end{array}$ & 77.52 & 45.50 & 64.41 & 59.31 \\
\hline Ash+sludge & 72.94 & 55.40 & 52.23 & 49.89 \\
\hline
\end{tabular}

\section{CONCLUSIONS}

Natural processes of soil formation affect the fate of chemical elements in different migration chains. It was established that red-brown clay depresses the vegetation of fruit and berry plants because of low level salinization. Limestones and marl clays are characterized with unsatisfactory conditions for the spread of root systems. The sands practically do not contain elements of nutrition for plants and do not have a moisture-retaining ability. The steady decline in mineral reserves brings up the question of the search for renewable energy sources. Introduction of resource-saving and waste-free production technologies in some environmentally safe rocks will improve the efficiency some of orchard life cycles and provide reliable ways to provide stable production. On reclaimed lands, the biomass productivity of Miscanthus and Switchgrass can reach 7.0-7.3 $\mathrm{t} \mathrm{DM} \mathrm{ha}^{-1}$. The application of various amendments leads to an increase in the parameters of vertical and horizontal growth from $2 \%$ to $40 \%$. Thus, the yield increases to 13.3-17 t DM ha ${ }^{-1}$. The greatest effect is the use of sewage sludge. Despite the fact that both Switchgrass and Miscanthus have the $\mathrm{C}_{4}$ photosynthesis system, making them very effective in biomass production, Switchgrass is more drought resistant compared to Miscanthus. Therefore, it is able to produce above-ground biomass more efficiently under condition of insufficient water supply. The content of heavy metals in the above-ground biomass of plants grown on reclaimed lands is quite low and varies from $4.2-4.5$ to $129.5-159.9 \mathrm{mg} / \mathrm{kg}$. Heavy metals by the intensity of their 
absorption by studied plants can be arranged in increasing order: $\mathrm{Cu}>\mathrm{Pb}>\mathrm{Zn}>\mathrm{Mn}>\mathrm{Fe}$. The content of heavy metals in the biomass of Miscanthus was higher than in Switchgrass by $20-30 \%$. The amendment application modified the physicochemical properties of soil, thereby enhancing the availability of heavy metals in the soil and increasing their accumulation in biomass. The addition of double dose of sewage sludge had the most significant effect and caused an increase in content of heavy metals by $90-165 \%$ for Miscanthus and by $124-333 \%$ for Switchgrass. The application of the amendments led to an increase in heavy metal uptake by the Miscanthus and Switchgrass biomass. The introduction of mineral fertilizers, ash and mixture of ash and sewage sludge contributed to an increase in the uptake of heavy metals by the biomass of both plant species on average 1.5-2.6 times. The application of a single dose of sewage sludge enhanced the uptake of metals by 2.2-5.2 times. The applying of a double dose of sewage sludge led to an increase in the uptake capacity by 3.4-4.8 times for Miscanthus, and by 5.5-10.6 times for Switchgrass. By changing soil characteristics, amendments indirectly affect the thermal behavior of Miscanthus and Switschgrass biomass. The greatest modifications are characteristic for leaf biomass and are associated mainly with the decomposition of volatile components and hemicellulose, as well as with the formation of an unburned residue. Amendments significantly affect the thermal stability of biomass at the initial stage of thermolysis. As regards the destruction of the main components (hemicellulose, cellulose and lignin), the effect of soil amendments is minimal. The substrata properties affect the thermal characteristics of the wood. Changes are manifested in the speed of reactions, the content of volatile components and changes in the ash content of wood.

\section{SUMMARY}

Profile differentiation of nutrients depends on the substrata texture, the type of water regime, redox conditions and humus state of the soil. It was very important to find out the features in changing the physical and chemical properties of rocks after they are on the earth's surface due to mining. The advantage for further use was given not only to the rock that has the best physical, mineralogical and chemical characteristics, but is suitable for growing different crops. The set of optimal options can be expanded with the improvement of apple tree plantations creation in reclaimed minelands in combination with measures of adaptive orchard husbandry development. Giant Miscanthus and Switchgrass grown on the mixture of loess-like loam and red-brown clay were studied. Five amendments were used to determine the effect of various additional fertilizers: ash of sunflower husk in amount $10 \mathrm{t} \mathrm{ha}^{-1}$, municipal sewage sludge $\left(10 \mathrm{tha}^{-1}\right)$, mixture of ash and sewage sludge $\left(10 \mathrm{t} \mathrm{ha}^{-1}\right)$, a double dose of sludge $\left(20 \mathrm{t} \mathrm{ha}^{-1}\right)$ and mineral fertilizer 
with a balance of nutrients $\mathrm{N}_{60}: \mathrm{P}_{60}: \mathrm{K}_{60} \mathrm{~kg} \mathrm{ha}^{-1}$. It was detected that on reclaimed lands, the biomass productivity of Miscanthus and Switchgrass can reach 7.0-7.3 t DM ha ${ }^{-1}$. The application of various amendments leads to an increase in the parameters of vertical and horizontal growth from $2 \%$ to $40 \%$. The greatest effect is the use of sewage sludge. The content of heavy metals in the above-ground biomass is quite low and varies from 4.2-4.5 to $129.5-159.9 \mathrm{mg} \mathrm{kg}$. The content of heavy metals in the biomass of Miscanthus was higher than in Switchgrass by $20-30 \%$. The amendment application modified the physicochemical properties of soil, thereby enhancing the availability of heavy metals in the soil and increasing their accumulation in biomass. By changing soil characteristics, amendments indirectly affect the thermal behavior of Miscanthus and Switschgrass biomass. The greatest modifications are characteristic for leaf biomass and are associated mainly with the decomposition of volatile components and hemicellulose, as well as with the formation of an unburned residue. Moreover, amendments significantly affect the thermal stability of biomass at the initial stage of thermolysis.

\section{REFERENCES}

1. Kharytonov M., Lyadska I., Kozechko V., Kalyna V., Babenko M., Babenko V., Garmash S.M. The nitrates nutrition status assessment and management of the horticultural crops in the steppe zone of Ukraine. ANNALS of Faculty Engineering Hunedoara - International Journal of Engineering. 2019, Tome XVII. P. 127-130.

2. Scousen J., Brown C. Establishment and growth of switchgrass and other biomass crops on surface mines. Journal American Society of Mining and Reclamation. 2014. Vol. 3(1). P. 136-156. https://doi.org/10.21000/ JASMR14010136

3. Ussiri D.A.N., Guzman J.G., Lal R., Somireddy U. Bioenergy crop production on reclaimed mine land in the North Appalachian region, USA. Biomass and Bioenergy. 2019. Vol. 125. P. 188-195. https://doi.org/10.1016/j.biombioe.2019.04.024

4. Jakovljević M., Lilić N., Kolonja B., Knežević D., Petrić M., Tadić V., Nedić M. Biomass production as renewable energy resource at reclaimed Serbian lignite open-cast mines. Thermal Science. 2015. Vol. 19 (3). P. 823-835. https://doi.org/10.2298/TSCI140626014J

5. Nakajima T., Yamada T., Anzoua K., Kokubo R., Noborio K. Carbon sequestration and yield performances of Miscanthus $\times$ giganteus and Miscanthus sinensis. Carbon Management. 2018. Vol. 9(4). P. 415-423. https://doi.org/10.1080/17583004.2018.1518106

6. Heaton, E.A., Dohleman F.G., Long S.P. Meeting US Biofuel goals with less land: the potential of Miscanthus. Global Change Biology. 2008. Vol. 14. P. 2000-2014. http://dx.doi.org/10.1111/j.1365-2486.2008.01662.x. 
7. Boehmel C., Lewandowski I, Claupein W. Comparing annual and perennial energy cropping systems with different management intensities.

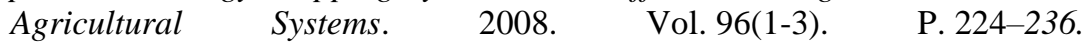
https://doi.org/10.1016/j.agsy.2007.08.004

8. Dohleman F.G., Heaton E.A., Leakey A.D.B., Long S.P. Does greater leaf-level photosynthesis contribute to greater solar energy conversion efficiency in Miscanthus when compared to switchgrass? Plant, Cell and Envorinmetal. 2009. Vol.32(11). P. 1525-1537. https://doi.org/10.1111/j.1365-3040.2009.02017.x

9. Khanna M., Dhengana B., Clifton-Brown J. Costs of producing miscanthus and switchgrass for bioenergy in Illinois. Biomass and Bioenergy. 2008. Vol. 32(6). P. 482-493. https://doi.org/10.1016/ j.biombioe.2007.11.003

10. Sadeghpour A., Hashemi M., DaCosta M., Jahanzad E., Herbert S. Switchgrass establishment influenced by cover crop, tillage system, and weed control. Bioenergy Research. 2014. Vol. 7. P. 1402-1410. https://doi.org/10.1007/s12155-014-9485-x

11. Xiaohan Yang, Ting Li, David Weston, Abhijit Karve, Jessy L. Labbe, Lee E. Gunter, Poornima Sukumar, Anne Borland, Jin-Gui Chen, Stan D. Wullschleger, Timothy J. Tschaplinski, Gerald A. Tuskan. Innovative Biological Solutions to Challenges in Sustainable Biofuels Production. In book:Biofuel Production-Recent Developments and Prospects. Edited by Dr. Marco Aurelio Dos Santos Bernardes. 2011. P. 375-414. https://doi.org/10.5772/17473

12. Stietiya M.H., Wang J.J. Effect of Organic Matter Oxidation on the Fractionation of Copper, Zinc, Lead, and Arsenic in Sewage Sludge and Amended Soils. J. Environ. Qual. 2011. Vol. 40. P. 1162-1171. https://doi.org/10.2134/jeq2011.0008

13. Soudani L., Heilmeier H.,Kharytonov M., Wiche O., Moschner C., Onyshchenko E., Bouchena N. (2017) Fertilization value of municipal sewage sludge for Eucalyptus camaldulensis plants. Biotechnology Reports. Vol. 13. P. 8-12. https://doi.org/10.1016/j.btre.2016.12.001

14. Dauber J., Brown C., Fernando A.L., Finnan J., Krasuska E., Ponitka J., Styles D., Thrän D., Van Groenigen K.J., Weih M., Zah R. Bioenergy from "surplus" land: environmental and socio-economic implications. BioRisk. 2012. Vol. 7. P. 5-50. https://doi.org/10.3897/biorisk.7.3036

15. Brian J.A., Jackson A.P. The behavior of heavy metals in sewage sludge-amended soil. Science of the Total Environment. 1991. Vol. 100. P. 151-176. https://doi.org/10.1016/0048-9697(91)90377-Q

16. Xiao R., Wang J.J., Gaston L.A., Zhou B., Park J.H., Li R., Dodla S. K., Zhang Z. Biochar produced from mineral salt-impregnated chicken manure: fertility properties and potential for carbon sequestration. 
Waste Management. 2018. Vol. 78. P. 802-810. https://doi.org/10.1016/ j.wasman.2018.06.047

17. Xiao R., Awasthi M.K., Li R.., Park J.S., Pensky Q., Wang J.J., Zhang Z. Recent developments in biochar utilization as an additive in organic solid waste composting: a review. Bioresour. Technol. 2017. Vol.246. P.203-213. https://doi.org/10.1016/j.biortech.2017.07.090

18. Singh R.P., Agrawal M. Potential benefits and risk of land application of sewage sludge. Waste Management. 2008. Vol. 28(2). P. 347-358. https://doi.org/10.1016/j.wasman.2006.12.010

19. Broido A. A simple, sensitive graphical method of treating thermogravimetric analysis data. J. Polymer of Science. 1969. Vol. 7(3). P. 1761-1763. https://doi.org/10.1002/pol.1969.160071012

20. Kharytonov M.M., Babenko M.G., Martynova N.V., Rula I.V., Klimkina I.I. 2018. Bioenergetic potential of switchgrass and sweet sorghum on the reclaimed lands. Development of natural sciences in countries of the European Union taking into account the challenges of XXI century: Collective monograph. Lublin : Izbevieciba "Baltija Publishing". 2018. P. 453-474.

21. Kharytonov M., Pidlisnyuk V., Stefanovska T., Babenko M., Martynova N., Rula I. The estimation of Miscanthus $\times$ giganteus adaptive potential for cultivation on the mining and post-mining lands in Ukraine. Environment Science and Pollution Research. 2019. Vol. 26 (3). P. 2974-2986. https://doi.org/10.1007/s11356-018-3741-0

22. Clifton-Brown J.C., Lewandowski I. Water-use efficiency and biomass partitioning of three different Miscanthus genotypes with limited and unlimited water supply. Ann. Bot. 2000. Vol. 86(1). P. 191-200. https://doi.org/10.1006/anbo.2000.1183

23. Burli P. Forgoston E., Lal P., Billings L., Wolde B. Adoption of switchgrass cultivation for biofuel under uncertainty: A discrete-time modeling approach. Biomass and Bioenergy. 2017. Vol. 105. P. 107-115. http://dx.doi.org/10.1016/j.biombioe.2017.06.012

24. Fike J.H., Parrish D.J., Wolf D.D., Balasko J.A., Green J.T., Rasnake M., Reynolds J.H. Long-term yield potential of switchgrass-for-biofuel systems. Biomass and Bioenergy. 2006. Vol. 30(3). P. 198-206. https://doi.org/10.1016/j.biombioe.2005.10.006

25. Wullschleger S.D., Davis E.B., Borsuk M.E., Gunderson C.A., Lynd L.R. Biomass Production in Switchgrass across the United States: Database Description and Determinants of Yield. Agronomy Journal. 2010. Vol. 102(4). P. 1158-1168. https://doi.org/10.2134/agronj2010.0087

26. Anderson E. Arundale R., Maughan M., Olandeinde A., Wycislo A., Voigt $\mathrm{T}$. Growth and agronomy of Miscanthus $\times$ giganteus for biomass production. Biofuels. 2011. Vol. 2(1). P. 71-87. https://doi.org/10.4155/ bfs. 10.80 
27. Mitchell R., Vogel K., Kenneth P., Uden D.R. The feasibility of switchgrass for biofuel production. Biofuels. 2012. Vol. 3(2). P. 47-59. http://digitalcommons.unl.edu/ncfwrustaff/169

28. Kalinina O., Nunn Ch., Sanderson R., Hastings A.F.S., Weijde T., Özgüven M., Tarakanov I., Schüle H., Trinidade L.M., Dolstra O., Schwarz K., Iqbal Y., Kiesel A., Mos M., Lewandowski I., Clifton-Brown J.C. Extending Miscanthus cultivation with Novel Germaplasm at six contrasting sites. Frontiers in Plant Science. 2017. Vol. 8. P. 1-15. https://doi.org/10.3389/fpls.2017.00563

29. Marra M., Keene T., Skousen J., Griggs T. Switchgrass yield on reclaimed surface mines for bioenergy production. J. Environ. Qual. 2013. Vol. 42(3). P. 696-703. http://doi.org/10.2134/jeq2012.0453

30. Scagline S., Skousen J., Griggs T. Switchgrass and miscanthus yields on reclaimed surface mines for bioenergy production. Journal American Society of Mining and Reclamation. 2015. Vol. 4(2). P. 80-90. http://doi.org/10.21000/JASMR15020080

31. Cherney J.H., Cherney D.J.R., Paddock K.M. Biomass Yield and Composition of Switchgrass Bales on Marginal Land as Influenced by Harvest Management Scheme. Bioenergy Research. 2018. Vol. 11(1). P. 34-43. https://doi.org/ 10.1007/s12155-017-9875-y

32.Zhang Ch., Guo J., Lee D.K., Anderson E., Huang H. Growth responses and accumulation of cadmium in switchgrass (Panicum virgatum L.) and prairie cordgrass (Spartina pectinata Link). RSC Advances. 2015. Vol. 102 (5). P. 83700-83706. https://doi.org/10.1039/C5RA13073E

33. Korzeniowska J., Stanislawska-Glubiak E. Phytoremediation potential of Miscanthus $\times$ giganteus and Spartina pectinata in soil contaminated with heavy metals. Environmental Science and Pollution Research. 2015. Vol. 22(15). P. 11648-11657. https://doi.org/10.1007/ s11356-015-4439-1

34. Castaldi P., Santona L., Melis P. Heavy metal immobilization by chemical amendments in a polluted soil and influence on white lupin growth. Chemosphere. 2005. Vol. 60(3). P. 365-371. https://doi.org/10.1016/ j.chemosphere.2004.11.098

35. Singh R.P., Agrawal M. Variations in heavy metal accumulation, growth and yield of rice plants grown at different sewage sludge amendment rates. Ecotoxicology and Environmental Safety. 2010. Vol. 73(4). P. 632-641.https://doi.org/10.1016/j.ecoenv.2010.01.020

36. Pavel P.B., Puschenreiter M., Wenzel W.W., Diacu E., Barbu C.H. Aided phytostabilization using Miscanthus sinensis $\times$ giganteus on heavy metal-contaminated soils. Science of The Total Environment. 2014. Vol. 479-480. P.125-131. https://doi.org/10.1016/j.scitotenv.2014.01.097

37. Zhou H., Zhou X., Zeng M., Liao B.H., Liu L., Yang W.T., Wu Y.M., Qiu .Y., Wang Y.J. Effects of combined amendments on heavy metal 
accumulation in rice (Oryza sativa L.) planted on contaminated paddy soil. Ecotoxicology and Environmental Safety. 2014. Vol. 101. P. 226-232. https://doi.org/10.1016/j.ecoenv.2014.01.001

38. Antonkiewicz J., Pełka R., Bik-Małodzińska M., Żukowska G., GleńKarolczyk K. The effect of cellulose production waste and municipal sewage sludge on biomass and heavy metal uptake by a plant mixture. Environmental Science and Pollution Research. 2018. Vol. 25. P. 3110131112. https://doi.org/10.1007/s11356-018-3109-5

\section{Information about authors: Kharytonov M. M.,}

Doctor of Agricultural Sciences, Professor, Professor Soil Science and Farming Department Dnipro State Agrarian and Economics University

25, Yefremov str., Dnipro, 49000, Ukraine

Martynova N. V.,

Dr., Candidate of Biological Sciences, Head of the Natural Flora Laboratory of the Botanical Garden Oles Honchar Dnipro National University 72, Gagarin av., Dnipro, 49000, Ukraine

Babenko M. G.,

Dr., Candidate of Agricultural Sciences, Chief of Land Reclamation Station Dnipro State Agrarian and Economics University 25, Yefremov str., Dnipro, 49000, Ukraine

Rula I. V., Dr., Candidate of Technical Sciences, Associate Professor of Chemistry Department Dnipro State Agrarian and Economics University 25, Yefremov str., Dnipro, 49000, Ukraine 